\title{
A comparative study of changes in the Lambert Glacier/Amery Ice Shelf system, East Antarctica, during 2004-2008 using gravity and surface elevation observations
}

\author{
HUAN XIE, ${ }^{1,2}$ RONGXING LI, ${ }^{1,2}$ XIAOHUA TONG, ${ }^{1,2}$ XIAOLEI JU, ${ }^{1,2}$ JUN LIU, ${ }^{1,2}$ \\ YUNZHONG SHEN, ${ }^{1,2}$ LEI CHEN, ${ }^{1,2}$ SHIJIE LIU, ${ }^{1,2}$ BO SUN, ${ }^{3}$ XIANGBIN CUI, ${ }^{3}$ \\ YIXIANG TIAN, ${ }^{1,2}$ WENKAI YE ${ }^{1,2}$ \\ ${ }^{1}$ Center for Spatial Information Science and Sustainable Development, Tongji University, 1239 Siping Road, Shanghai \\ 200092, China \\ ${ }^{2}$ College of Surveying and Geo-Informatics, Tongji University, 1239 Siping Road, Shanghai 200092, China \\ ${ }^{3}$ Polar Research Institute of China, 451 Jinqiao Road, Shanghai 200136, China \\ Correspondence: Rongxing Li <RonLi_282@hotmail.com>
}

\begin{abstract}
We present results of a regional comparative study of surface mass changes from 2004 to 2008 based on Gravity Recovery and Climate Experiment (GRACE), The Ice, Cloud and Land Elevation Satellite (ICESat) and CHINARE observations over the Lambert Glacier/Amery Ice Shelf system (LAS). Estimation of the ICESat mass change rates benefitted from the density measurements along the CHINARE traverse and a spatial density adjustment method for reducing the effect of spatial density variations. In the high-elevation inland region, a positive trend was estimated from both ICESat and GRACE data, which is in line with the CHINARE accumulation measurements. In the coastal region, there were areas with high level accumulations in both ICESat and GRACE trend maps. In many high flow-speed glacier areas, negative mass change rates may be caused by dynamic ice flow discharges that have surpassed the snow accumulation. Overall, the mass change rate estimate in the LAS of 2004-2008 from the GRACE, ICESat and CHINARE data is $5.41 \pm 4.59 \mathrm{Gt}^{-1}$, indicating a balanced to slightly positive mass trend. Along with other published results, this suggests that a longerterm positive mass trend in the LAS may have slowed in recent years.
\end{abstract}

KEYWORDS: GRACE, ICESat, Lambert-Amery System, mass changes

\section{INTRODUCTION}

Monitoring of mass changes in Antarctica has become an important research topic because melting of the Antarctic ice sheet (AIS) and the resulting discharge contribute significantly to changes in the sea level (Bamber and others, 2009b; Cazenave and Llovel, 2010; Shepherd and others, 2012; Vaughan and others, 2013). The contribution of changes in the polar ice sheet to rising sea levels displays an accelerating trend compared with changes in the other two major contributors: continental glaciers and expansion of seawater caused by higher temperatures (Domingues and others, 2008; Chen and others, 2009; Cazenave and Llovel, 2010; Rignot and others, 2011a; Zwally and Giovinetto, 2011). Both its vast ice mass and its increasing rate of change make observations of the AIS a high priority. Furthermore, the potential instability of the ice sheet due to effects related to accelerated ice flow, subsurface lakes and basal ice-shelf melting may significantly affect the overall rate of change, and the ice sheet needs to be closely monitored and modeled using regional and local observations (Ivins, 2009; Flament and others, 2013; Moholdt and others, 2014; Liu and others, 2015; Paolo and others, 2015).

Analysis of changes in the AIS can be performed using remote-sensing technologies, including among others, mass change measurements from satellite gravimeters and surface elevation measurements from satellite altimeters. Satellite gravimeters quantify the total mass variations produced by variations in all layers underlying the remotesensing footprint. The major missions providing satellite gravimeter data started with Challenging Mini-satellite Payload (CHAMP) in 2000 (Reigber and others, 2002a), followed by Gravity Recovery and Climate Experiment (GRACE) in 2002 (Tapley and others, 2004a) and Gravity Field and Steady State Ocean Circulation Explorer (GOCE) in 2009 (Drinkwater and others, 2003). One major goal of the CHAMP mission was to improve knowledge of the Earth's gravity field (Reigber and others, 2002b). In this mission, the low precision resulted in insufficient data concerning time-variable components of the gravity field. GOCE was specifically designed to measure the static gravity field (geoid and gravity anomalies) with high accuracy and spatial resolution (Rummel and others, 2002). The GRACE mission launched a set of twin satellites on 17 March 2002. These satellites have been collecting detailed monthly measurements of Earth's gravity field at a resolution of $\sim 400 \mathrm{~km}$ and an accuracy of $\sim 1.5 \mathrm{~cm}(1 \sigma)$ w.e. height at spatial scales $>\sim 800 \mathrm{~km}$, and the measurements include those in Antarctica (Wahr and others, 2004; Chen and others, 2006).

In contrast to gravimeters, satellite altimeters directly measure ice-sheet surface elevations. Radar altimetry technology was realized in European Remote-Sensing (ERS) missions ERS-1 and ERS-2, which completed operations in 2000 and 2011, respectively (Davis, 1992). Another radar 
altimeter aboard the Envisat (Environmental Satellite) mission operated from 2002 to 2010 (Rémy and Parouty, 2009; Memin and others, 2014). The Ice, Cloud and Land Elevation Satellite (ICESat) and Earth Explorer Opportunity Mission-2 (CryoSat-2) missions have been supplying laser and radar altimetric data on the vertical changes in the surface of Antarctica from 2003 to the present (Drinkwater and others, 2004; Schutz and others, 2005; Wingham and others, 2006a; McMillan and others, 2014), with a short gap from 2009 to 2010 that can be partially filled with data from NASA's Operation IceBridge (Koenig and others, 2010). The ICESat mission acquired valuable data on elevation changes in the Greenland ice sheet (GIS) and AIS between 2003 and 2009 using its geoscience laser altimeter system (GLAS) (Zwally and others, 2002). The GLAS/ICESat included a $1064 \mathrm{~nm}$ laser channel for surface altimetry and was designed for a range measurement precision of $10 \mathrm{~cm}$. It achieved an accuracy $(1 \sigma)$ of $14 \mathrm{~cm}$ in its surface elevation measurements (Schutz and others, 2005; Shuman and others,

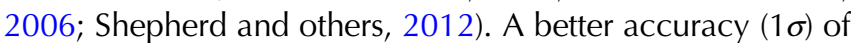
$5 \mathrm{~cm}$ was achieved under optimal conditions (Fricker and others, 2005; Moholdt and others, 2010).

The GRACE and ICESat missions were expected to provide advanced time series data on changes in the AIS. A comparison of the secular mass changes in the AIS derived from the two independent GRACE and ICESat datasets over a period from 2003 to 2007 indicated a correlation between the two (Gunter and others, 2009). Ewert and others (2012) presented a similar approach to a comparative study of mass changes in the GIS from 2003 to 2008 that were estimated from GRACE and ICESat data. The derived mass changes indicated a consistent overall rate of change in the GIS when an appropriate firn density was chosen, whereas the change rates in individual basins appear to feature lower degrees of agreement. A similar study on the estimation of Antarctic height and mass change rates was introduced by Memin and others (2014) using Envisat radar altimetry data for 2003-2010. A reconciled estimate of the ice-sheet mass balance using a variety of remote sensing and in situ observations, including GRACE and ICESat data, was reported by Shepherd and others (2012).

This study focuses on regional ice-sheet changes in the Lambert Glacier/Amery Ice Shelf system (LAS), East Antarctica. As illustrated in Figure 1, the LAS study area (red wedge) is located in the region of $66.5-81^{\circ} \mathrm{S}$ and $40-95^{\circ} \mathrm{E}$, covering an area of $2427820 \mathrm{~km}^{2}$. This region was extended from the LAS area $\left(68.5-81^{\circ} \mathrm{S}\right.$ and $\left.40-95^{\circ} \mathrm{E}\right)$ defined by Fricker and others (2000) to include four tributary basins (Basins 2, 3, 5 and the most of Basin 4 in Fig. 1) contributing to the mass balance of the Amery Ice Shelf. The LAS is the largest glacier/ ice shelf system in East Antarctica.

The area of the grounded portion of the LAS is 16\% of the East AIS (Fricker and others, 2000). Although change in areal extent is not directly related to change in the mass balance in Antarctica, the two are linked (Foley and others, 2013). Table 1 lists published estimates of the trends in mass changes in the LAS from 1992 to 2013 using various data and methods. Certain publications have presented estimated mass changes for all of Antarctica and specific changes at the basin level. Others have used basins defined by various boundaries and presented differences for comparison. We recalculated the mass change rates in the LAS and surroundings in our study area, illustrated in Figure 1, based on published results (Table 1). Our recalculation used an area-based adjustment method that is explained in the Supplementary Material.

The first two estimated trends for the LAS in Table 1 by Zwally and others (2005) and Wingham and others (2006b) span the period, 1992-2003 and used the long-term observations of the ERS- 1 and -2 radar altimeters. The recalculated trends in the LAS were based on the results for the entire Antarctica. The results reached the opposite trends of $-13 \pm 7 \mathrm{Gt} \mathrm{a}^{-1}$ for 1992-2001 and $14 \pm 1 \mathrm{Gt} \mathrm{a}^{-1}$ for 19922003 in the LAS. Zwally and Giovinetto (2011) compared the two opposite ERS-based estimates for the entire AIS. Among the differences discussed, the factors that may have

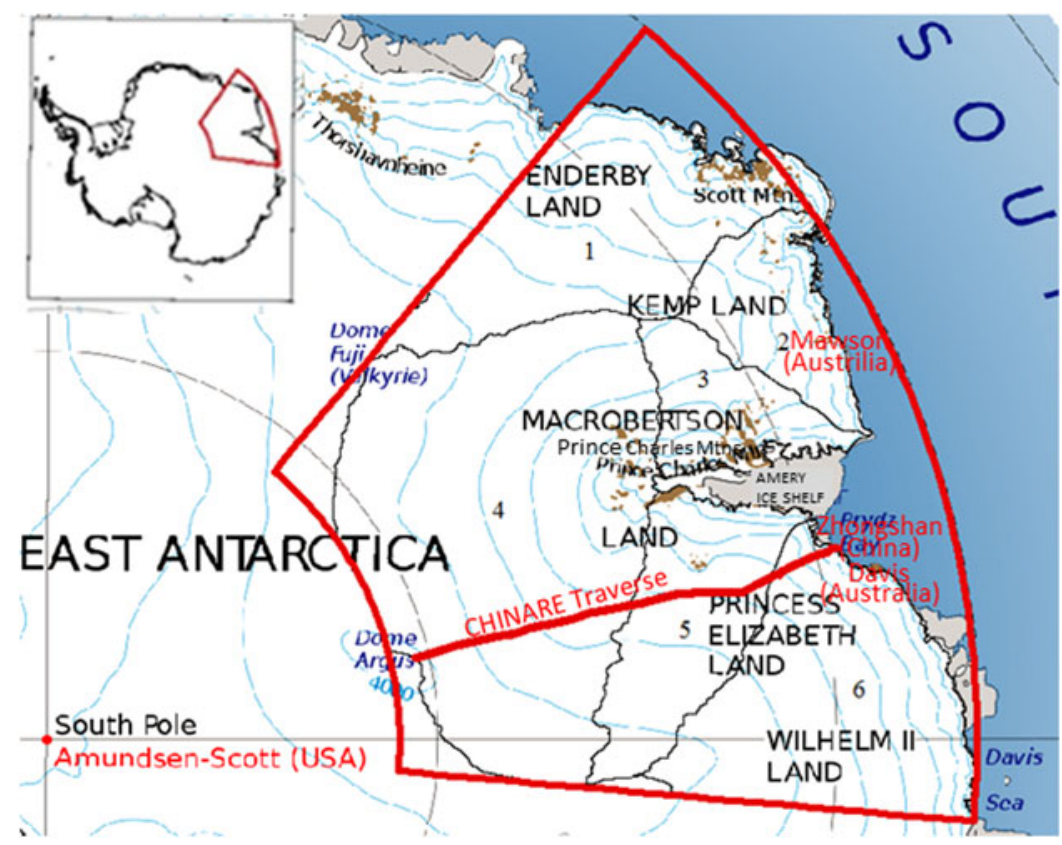

Fig. 1. Study area (red wedge) of LAS, $66.5-81^{\circ} \mathrm{S}$ and $40-95^{\circ} \mathrm{E}$, modified from an Antarctica Overview Map produced by LIMA (2012). The red outline indicates the CHINARE traverse from Zhongshan station to Dome A. Accumulation basins, 1-6 are labeled. 
Table 1. Trends in the mass change estimates for the LAS from 1992 to 2013 by different authors

\begin{tabular}{lllc}
\hline Author & Method/sensor & Period & $\begin{array}{c}\text { Trend } \\
\text { Gt a }{ }^{-1}\end{array}$ \\
\hline Zwally and others (2005) & ERS-1 \& -2 & Apr 1992-Apr 2001 & $-13 \pm 7$ \\
Wingham and others (2006b) & ERS-1 \& -2 & Oct 1992-Feb 2003 & $14 \pm 1$ \\
Ren and others (2002) & In situ measurements & $1994-1999$ & 17 \\
Rignot and others (2008) & InSAR, snow accumulation data & 2000 & $-14 \pm 25$ \\
Yu and others (2010) & InSAR, snow accumulation data & 2000 & $42 \pm 8$ \\
King and others (2012) & GRACE RL04 GIA(W12a) & Aug 2002-Dec 2010 \\
Sasgen and others (2013) & GRACE (GFZ RL05 \& CSR RL05) GIA(AGE1) & Jan 2003-Sep 2012 & $36 \pm 11$ \\
Present study (2016) & ICESat R633 & Feb 2004-Oct 2008 & $35 \pm 8$ \\
McMillan and others (2014) & GRACE CSR RL05 & Oct 2010-Sep 2013 & $2.41 \pm 4.59$
\end{tabular}

caused the different regional estimates in the LAS include the firn density and data coverage in the high slope coastal region. Zwally and others (2005) considered the mass changes of 1992-2001 as a long-term imbalance and used a density of $900 \mathrm{~kg} \mathrm{~m}^{-3}$ for the firn/ice column. A firn compaction correction using the firn temperature was also applied. Considerations of the elevation changes in the upper firn layers or the whole firn/ice column were given by Wingham and others (2006b) to reach a preferred estimate. Corrections for accumulation anomalies in 19922001 determined from atmospheric modeling were applied. No conclusive suggestion was given by Zwally and Giovinetto (2011) for a choice between the two estimates for the AIS. Although we also cannot favor either estimate, the available in situ density measurements along the CHINARE traverse can be applied to analyze the effect of the density uncertainty on the altimetry-based trend estimation.

Ren and others (2002) performed a study of the LAS. An increase of $17 \mathrm{Gt} \mathrm{a}^{-1}$ during the period, 1994-1999 was estimated from in situ measurement data of ice flow speed and accumulation. These data were obtained using GPS measurements and bamboo stakes along a Chinese expedition route (CHINARE traverse in Fig. 1) and an Australian ANARE expedition route. No exact study area boundary or error estimate was presented.

Rignot and others (2008) used InSAR data and snow accumulation data to estimate the Antarctic mass change in 2000, while Yu and others (2010) performed another study specifically for the LAS in 2000 based on RADARSAT images, snow accumulation and in situ observations. Again, the two recalculated trends for the LAS in 2000 are opposite, $-14 \pm 25 \mathrm{Gt} \mathrm{a}^{-1}$ by Rignot and others (2008) and $42 \pm 8 \mathrm{Gt} \mathrm{a}^{-1}$ by $\mathrm{Yu}$ and others (2010). In this case, the period and the speed information are both from InSAR data. However, one of the important information sources used in the computations is the snow accumulation data. The mass-balance study of Yu and others (2010) was specifically for the LAS. The regional accumulation was determined by using the accumulation data interpolated from in situ observations and the tributary sub-basin boundaries that were specifically remapped from ICESat data and satellite images. Its positive trend is also in line with the published estimates of more recent years.

King and others (2012) estimated an Antarctic mass balance based on GRACE data from 2002 to 2010 using the W12a GIA model (a glacial isostatic adjustment (GIA) model), and we recalculated an estimated regional LAS trend of $36 \pm 11 \mathrm{Gt} \mathrm{a}^{-1}$. Furthermore, a positive trend of $35 \pm 8 \mathrm{Gt} \mathrm{a}^{-1}$ in the LAS during the period of 2003-2012 was recompiled from Antarctic results from GRACE data published by Sasgen and others (2013). These two estimates from the GRACE data during a largely overlapping period are consistent in the LAS.

Based on CryoSat-2 data spanning the period, 20102013, a smaller estimated increase of $2 \pm 18 \mathrm{Gt} \mathrm{a}^{-1}$ was obtained from the Antarctic results of McMillan and others (2014).

The first five estimated trends in the LAS in Table 1 are from 1999 to 2003, and were derived from the earlier satellite radar altimetry and InSAR observations and ground measurements. The significant discrepancies may be mainly attributed to the lack of regional knowledge such as the firn density distribution and high-quality accumulation, which are important for the methods based on altimetry data and regional input/ output information. The three more recent trends from 2002 to 2013 in Table 1 were estimated from the GRACE and CryoSat-2 data and showed consistently positive trends, which are partly in line with the overall positive trend of $26 \pm 36 \mathrm{Gt} \mathrm{a}^{-1}$ in East Antarctica from 2000 to 2011, which was estimated by reconciling results from gravimetry, altimetry and input/output methods (Shepherd and others, 2012). Furthermore, there seems to be a difference in the positive trend magnitude in the LAS between the longer-term estimate of $36 \pm 11 \mathrm{Gt} \mathrm{a}^{-1}$ (2002-2010; GRACE) and the shorter-term estimate of $2 \pm 18 \mathrm{Gt} \mathrm{a}^{-1}$ (2010-2013; CryoSat-2). It is valuable to perform a systematic investigation by using overlapping satellite and in situ observations in the LAS to contribute to the understanding of the regional dynamics.

The objectives of this study were: (1) to evaluate and compare the mass change rates in the LAS region based on GRACE and ICESat data from 2004 to 2008, and (2) to use in situ CHINARE observations, in the context of previous studies, to improve the regional estimates and to help resolve discrepancies in LAS mass change estimates. In the following sections, the methodologies used for the GRACE and ICESat regional data processing were introduced. Trend estimates and spatial variations were achieved in both the LAS region and its individual basins. The elevation change rate derived from the ICESat data was compared with the height change (accumulation) rate calculated from the snow-stake data collected along the CHINARE expedition traverse. GIA corrections and the in situ measurements of the firn density of CHINARE were taken into account before the comparative analysis. Discussions and conclusions are drawn in the later sections. 


\section{MASS CHANGE ESTIMATION FROM GRACE OBSERVATIONS}

\subsection{GRACE data processing method}

The officially released RL05 GRACE monthly gravity field models are available on the website of the International Centre for Global Earth Models (http://icgem.gfz-potsdam. de/ICGEM/). Other contributing GRACE monthly models, including the Tongji-GRACE01 model (Chen and others, $2015 \mathrm{a}, \mathrm{b})$, are also available on the same website. Using elastic loading theory (Farrell, 1972), the Stokes coefficients can be used to calculate a surface mass anomaly $\Delta \sigma$ at a location (Wahr and others, 1998) using the expression

$$
\begin{aligned}
\Delta \sigma(\theta, \lambda)= & \frac{a \rho_{\text {ave }}}{3} \sum_{l=0}^{N_{\max }} \sum_{m=0}^{l} \frac{2 l+1}{1+k_{l}} \bar{P}_{l m}(\cos \theta) \\
& \times\left(\Delta C_{l m} \cos (m \lambda)+\Delta S_{l m} \sin (m \lambda)\right),
\end{aligned}
$$

where $\theta$ and $\lambda$ are the colatitude and longitude; $a$ is the semimajor radius of the Earth; $\rho_{\text {ave }}$ is the average density of the Earth $\left(5517 \mathrm{~kg} \mathrm{~m}^{-3}\right) ; \bar{P}_{I m}(\cos \theta)$ is the normalized associated Legendre function; $k_{l}$ is the /th Love number; $\Delta C_{l m}$ and $\Delta S_{l m}$ are the time-variable Stokes coefficients with $I$ and $m$ being the degree and order, respectively; and $N_{\max }$ is the maximum degree of the time-variable gravity solution from the GRACE measurements.

Estimates of the monthly mass changes are the basic information used to calculate the mass change rate. Suppressing noise in the monthly GRACE data is important for the reliability of the mass change analysis. Much of the spatial noise in the surface mass change fields derived from the GRACE data, which are represented as north/south-oriented stripes, is caused by correlations among estimated spherical harmonics, with extra noise increasing with the spherical harmonic degree (Swenson and Wahr, 2006). We eliminated these inter-coefficient correlations using a two-step filtering procedure. The first step involves the method of Chen and others $(2007,2009)$, which removes the correlation noise at spherical harmonic orders of eight or more. This method fits a third-order polynomial to a set of even or odd coefficients corresponding to each order. Then, the polynomial is subtracted from the coefficients. This method is referred to as P3M8 and has been proved to be effective in reducing noise and preserving geophysical signals (Liu, 2008; Zhao and others, 2011). The second step involved applying an anisotropic Fan filter with averaging radii of $300 \mathrm{~km}$ to both the degree and order (Zhang and others, 2009; Tang and others, 2012) with the goal of suppressing any remaining noise in the monthly anomalies. After the Fan filtering functions $W_{l}$ and $W_{m}$ are introduced, Eqn (1) is rewritten (Wahr and others, 1998; Luo and others, 2012) as follows:

$$
\begin{aligned}
\Delta \sigma(\theta, \lambda)= & \frac{a \rho_{\text {ave }}}{3} \sum_{l=0}^{N_{\max }} \sum_{m=0}^{l} \frac{2 l+1}{1+k_{l}} \bar{P}_{l m}(\cos \theta) W_{l, m} \\
& \times\left(\Delta C_{l m} \cos (m \lambda)+\Delta S_{I m} \sin (m \lambda)\right),
\end{aligned}
$$

where $W_{l, m}=W_{l} \times W_{m} . W_{l}$ and $W_{m}$ are recursively calculated using the equations $W_{l+1}=-(2 l+1 / b) W_{l}+W_{l-1}$ and $W_{m+1}=-(2 l+1 / b) W_{m}+W_{m-1}$ based on the initial values of $W_{0}=1, W_{1}=-\left(1+e^{-2 b} / 1-e^{-2 b}\right)-(1 / b)$ and $b=\ln (2) /$ $(1-\cos (r / a))$. The variable $r$ is the radius of the Fan filtering (Jekeli, 1981; Zhang and others, 2009) and was set to a value of $300 \mathrm{~km}$ based on the resolution of the Center for Space Research (CSR solutions).

In the CSR RL05 data, SLRF2005/LPOD2005, which is consistent with ITRF2005, was used. The mass density change $\Delta \sigma$ $(\theta, \lambda)$ was converted to a change in the equivalent water height $(\mathrm{EWH}), \Delta h(\theta, \lambda)$, by dividing by the density of water. This method for processing the GRACE data can be applied to the entire Earth. However, there are some special considerations when applied to Antarctica. For example, Figure 2 shows the estimated global cumulative mass density anomalies from February 2006 to October 2006, which were estimated using the monthly gravity field solutions (GSM coefficients or GRACE Stokes coefficients as denoted by the GRACE project) with the inserted degree-one coefficients (Fig. 2a) and from the GSM without the degree-one coefficients (Fig. 2b). Adding the degree-one coefficients notably changes the gravity anomaly values, especially in Antarctica. For implementation, the geocenter parameters were obtained from ftp.csr.utexas.edu/pub/slr/geocenter/ (Chen and others, 2008) and the terms were calculated by using equations from Barletta and others (2013).

Figure 3 shows the results of the two-step processing of the inter-coefficient correlation removal and filtering. The annual mass anomaly in Antarctica from February 2004 to February 2005, calculated from the monthly GRACE data solutions via least squares fitting, exhibits meridional stripes in Figure $3 a$. These stripes were attenuated in Figure $3 \mathrm{~b}$ after the P3M8 decorrelation. In another example, the residual noise after
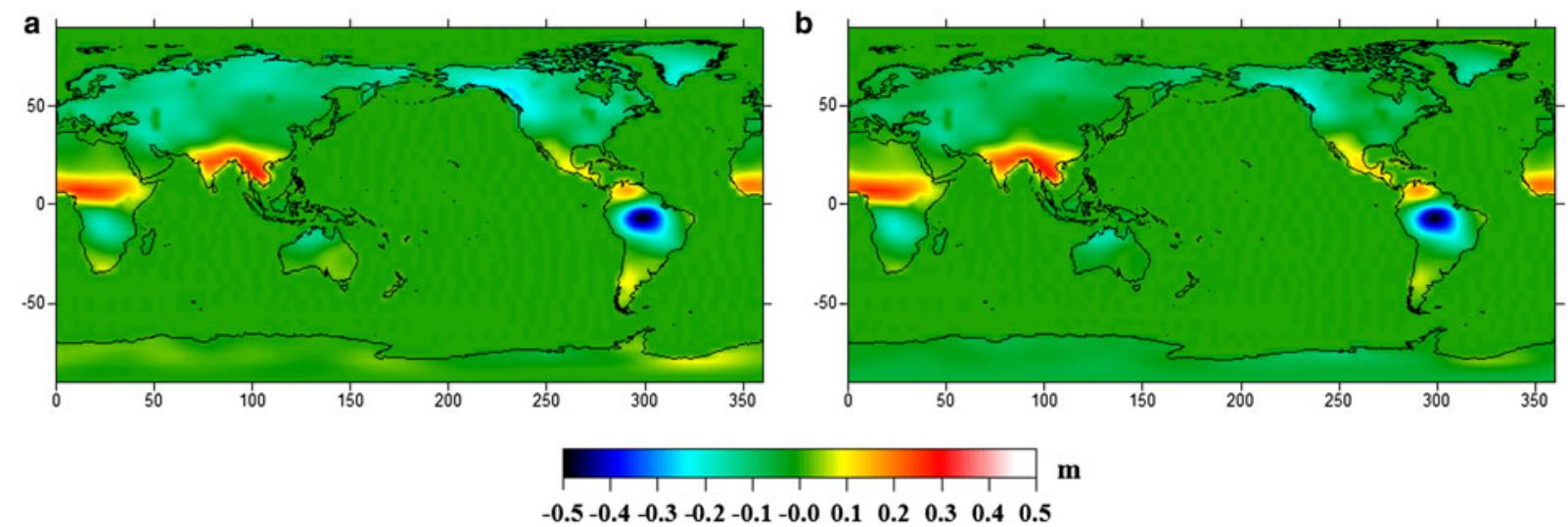

Fig. 2. Global cumulative mass density anomalies (EWH) (m) derived from GRACE data from February 2006 to October 2006 : (a) estimate using GSM with inserted degree-one coefficients and (b) estimate using GSM without degree-one coefficients. 
a
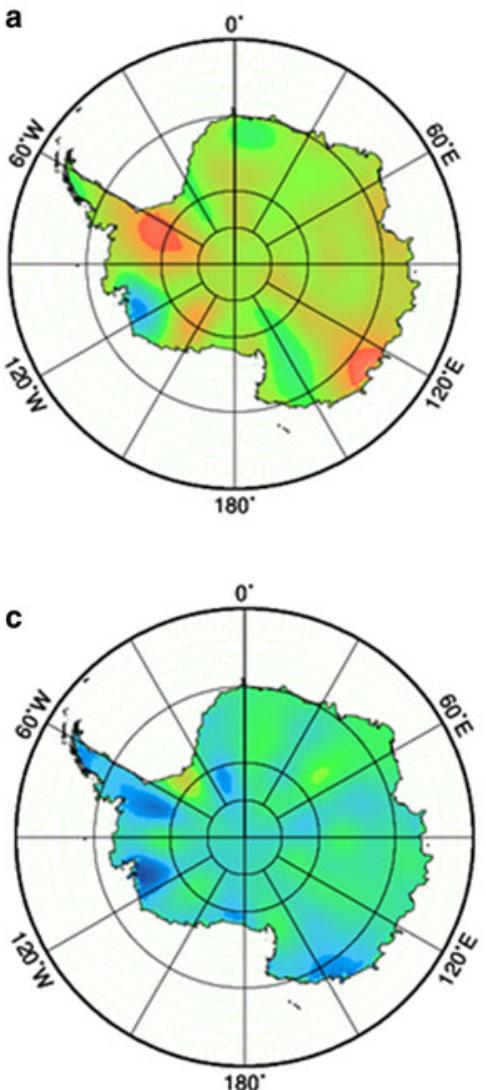

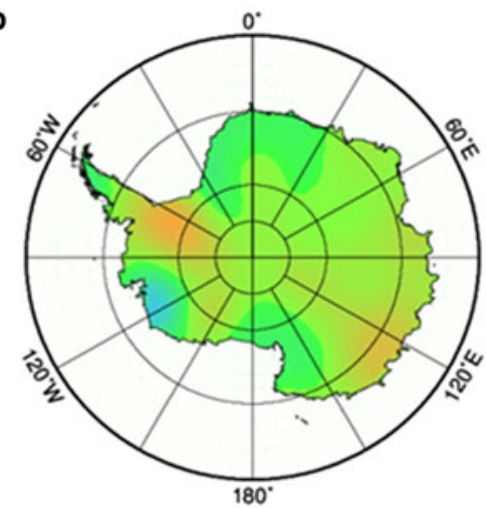

d

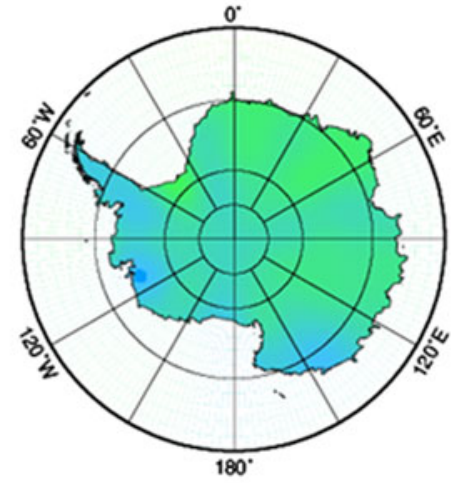

$\mathrm{cm}$

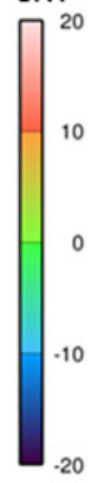

$\mathrm{cm}$

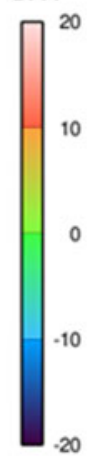

Fig. 3. Effectiveness of inter-coefficient decorrelation and Fan filtering: (a) annual mass anomaly of Antarctica from February 2004 to February 2005 computed from GRACE data, (b) meridional stripes removed by P3M8 decorrelation; (c) mass anomaly (after P3M8 decorrelation) from October 2004 to February 2005 with significant residual noise filtered by a Gaussian filter, and (d) mass anomaly results using a Fan filter instead of a Gaussian filter.

the application of the P3M8 decorrelation to the mass anomaly from October 2004 to February 2005 remains significant when filtered by a Gaussian filter with a window size of $500 \mathrm{~km}$ (Fig. 3c). However, the Fan filter with a window size of $300 \mathrm{~km}$ is effective in removing the noise (Fig. 3d)

Corrections for atmospheric and oceanic effects are performed by the GRACE Project, and these signals were removed from the level-one data released by the GRACE processing centers (Bettadpur, 2007a, b; Swenson and others, 2008; Velicogna and Wahr, 2013). Velicogna and Wahr (2013) indicated that the residual errors due to atmospheric effects in the released GRACE data are negligible with regard to mass-balance estimates of the entire ice sheet. We did not perform any additional atmospheric corrections.

A GIA was applied, which corrects for the overall upward rebound movement caused by the post-glacial recovery in Antarctica (Nakada and others, 2000; Ivins and James, 2005). GIAs have been used in many applications, such as crustal movement (mainly in the vertical direction), sealevel change, gravity fields, earth rotation and earth stress (Lambeck, 1977; Sabadini and Vermeersen, 2004; Wang and others, 2009; Yamamoto and others, 2010). Three GIA models are used in this study - the Paulson 2007 (Paulson and others, 2007), W12a (Whitehouse and others, 2012) and IJ05 (Ivins and others, 2013) models - to compare the effects of various GIA models. Finally, a temporal filter involving a moving-window average based on three months of GSM was applied to remove temporal noise (Chen and others, 2015a, b).

\subsection{Mass changes in the LAS estimated from GRACE data}

The GRACE gravity data (RL05) used in this study were released by the CSR at the University of Texas. In late 2013, when the study was initiated, the RL05 level-2 data covered the period, 2004-2010. The GRACE observations in this study only cover 2004-2008 so the processed GRACE data will overlap with the available ICESat data. The GRACE observations are presented as Stokes coefficients at monthly intervals up to the spectral degree and order of 60 , which translates to a half-wavelength spatial resolution of $\sim 300 \mathrm{~km}$. In level-2 data processing, tidal effects, including those of the ocean, solid earth and solid earth pole tides (rotational deformation), and non-tidal atmospheric and oceanic contributions were removed in the de-aliasing process (Bettadpur, 2007a). Compared with previous data releases, the $\mathrm{C}_{20}$ values of RL05 were improved by reducing north/south stripes and east/west banded errors by performing other minor enhancements (Bettadpur and others, 2012). The degree-one coefficients, which are related to the geocenter motion, are not captured by GRACE. Therefore, the degree-one harmonic coefficients are calculated from geocenter parameters and are inserted into the gravity field (Chen and others, 2008; Swenson and others, 2008; Baur and others, 2013). 


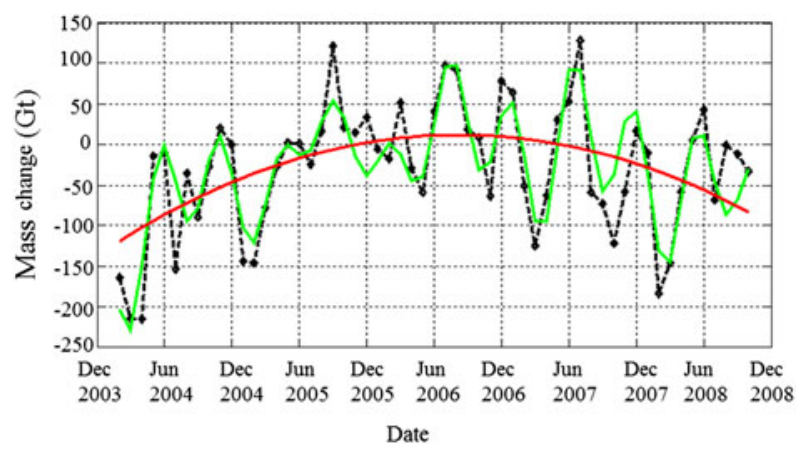

Fig. 4. Monthly mass solutions (black diamonds) from February 2004 to October 2008 computed from GRACE data and the IJ05 R2 GIA model. They are fitted to a second-order model (green curve) with a linear trend, acceleration, annual and semiannual terms, and a S2 tide aliasing term. The red curve illustrates the combined linear trend and acceleration terms.

Figure 4 shows the monthly solutions of mass changes in the LAS (denoted by black diamonds) from February 2004 to October 2008 (57 months). The IJ05 R2 GIA model was employed. We fitted the monthly solutions to a model (green curve) containing a linear trend, an acceleration, annual and semiannual terms and a $161 \mathrm{~d}$ tide aliasing term (S2) (Chen and others, 2009). The estimated overall trend in the LAS is $7.7 \pm 5.9 \mathrm{Gt} \mathrm{a}^{-1}$, and the acceleration is $-20.6 \pm 2.8 \mathrm{Gt} \mathrm{a}^{-2}$. The annual and semiannual amplitudes are $40.7 \pm 11.7 \mathrm{Gt}$ and $30.4 \pm 11.8 \mathrm{Gt}$, respectively. The tide aliasing term was $54.4 \pm 11.7 \mathrm{Gt}$. Thus, the overall mass change in the LAS from February 2004 to October 2008 is $35.8 \pm 27.6 \mathrm{Gt}$, based on the trend of $7.7 \pm 5.9 \mathrm{Gt} \mathrm{a}^{-1}$ and the time span.

The overall mass change rate in the LAS and the trends at the basin level estimated from the 2004-2008 GRACE data are illustrated in the last column of Table 2. Basins 1, 2 and 3 show positive trends of $1.37 \pm 0.82,0.92 \pm 0.29$ and 0.71 $\pm 0.27 \mathrm{Gt} \mathrm{a}^{-1}$. The corresponding spatial pattern is clearly shown in Figure 12b. The other three basins (Basins 4, 5 and 6) have the estimated trends that are indistinguishable from zero. The trends estimated from the GRACE and ICESat data at the basin level are compared below. Note that the entire study area is larger than the sum of all the basin areas.

The observational errors are contained in the monthly GRACE gravity field solutions, which are further propagated to the estimated parameters, such as the trend, acceleration and others. Differences were calculated between the fitted curve in Figure 4 and the 57 monthly mass change solutions (black diamonds in Fig. 4) that were calculated based on the Stokes coefficients. The least-squares method that was used to estimate the parameters used these differences to calculate the variance of unit weight and variances of the estimated parameters through an error propagation law (Wahr and others, 2006; Horwath and Dietrich, 2009; Ewert and others, 2012; Luo and others, 2012). Consequently, the estimated linear trend of $7.66 \mathrm{Gt} \mathrm{a}^{-1}$ has an uncertainty of $5.91 \mathrm{Gt} \mathrm{a}^{-1}$. This uncertainty represents the effect of all categories of errors in the gravity field solutions.

The truncation of the spherical harmonic expansion and the filtering of the weight function resulted in so-called leakage errors. Leakage errors can be induced by changes in the storage of liquid water and snow on land beyond the ice sheet, ocean mass variability and ice loss from nearby ice caps. In Antarctica, this error can be as large as $20 \mathrm{Gt} \mathrm{a}^{-1}$ and tends to be greatest in West Antarctica, depending primarily on the weight function and filtering methods (Velicogna and Wahr, 2013). We used a hydrological model, the Global Land Data Assimilation System (GLDAS, version 1), to compute the leakage effect from water and snow on land beyond the ice sheet. The resulting values were then converted to spherical harmonic gravity coefficients and were removed from the GRACE Stokes coefficients (Velicogna and Wahr, 2013). The leakage error in the LAS estimate using GLDAS is $1.59 \mathrm{Gt} \mathrm{a}^{-1}$, and this value was used to correct the gravity field solutions.

The largest uncertainties result from the differences in the GIA corrections based on different models. We calculated corrections using three GIA models, namely the IJ05 R2, Paulson 2007 and W12a models. The resulting trends are $7.66 \pm 5.91,3.25 \pm 6.88$ and $30.38 \pm 7.86 \mathrm{Gt} \mathrm{a}^{-1}$, respectively. The largest difference (between Paulson 2007 and W12a) is $27.13 \mathrm{Gt} \mathrm{a}^{-1}$. We used the result that applied corrections of the IJ05 R2 GIA model because its result is closest to the average of the results from the three GIA models investigated in this study. In addition, it has been used in many Antarctic mass-balance studies and fits well with Antarctic global GPS observations (Shepherd and others, 2012).

Figure 5 presents the spatial distribution of GIA corrections from the IJ05 model in the forms of the mass correction (integrated at a resolution of $1^{\circ} \times 1^{\circ}$ ) and elevation correction (uplift). The spatial variation in the mass changes estimated from GRACE data is shown in Figure 12b.

\section{MASS CHANGE ESTIMATION FROM ICESAT DATA}

\subsection{ICESat data processing method}

Mass changes can also be derived from ICESat observations of ice-sheet surface elevation change (SEC) (Zwally and

Table 2. Elevation and mass change rates and uncertainties (1 $\sigma$ ) derived from 2004-2008 ICESat and GRACE data at the basin level (Fig. 1)

\begin{tabular}{|c|c|c|c|c|c|}
\hline Basin & $\begin{array}{l}\text { Area } \\
\mathrm{km}^{2}\end{array}$ & $\begin{array}{l}\text { Trend from } \\
\text { ICESat } \\
\mathrm{cm} \mathrm{a}^{-1}\end{array}$ & $\begin{array}{c}\text { Trend from ICESat (I) } \\
\left(\text { density }=382 \mathrm{~kg} \mathrm{~m}^{-3}\right) \\
\mathrm{Gt} \mathrm{a}^{-1}\end{array}$ & $\begin{array}{l}\text { Trend from ICESat (II) } \\
\text { (density revised) } \\
\text { Gt a }{ }^{-1}\end{array}$ & $\begin{array}{l}\text { Trend from } \\
\text { GRACE } \\
\mathrm{Gt} \mathrm{a}^{-1}\end{array}$ \\
\hline 1 & 424558 & $-1.0 \pm 2.7$ & $-1.54 \pm 4.37$ & $-1.59 \pm 4.51$ & $1.37 \pm 0.82$ \\
\hline 2 & 159741 & $-0.7 \pm 5.0$ & $-0.40 \pm 3.02$ & $-0.42 \pm 3.19$ & $0.92 \pm 0.29$ \\
\hline 3 & 145322 & $5.4 \pm 5.4$ & $2.99 \pm 2.98$ & $3.08 \pm 3.07$ & $0.71 \pm 0.27$ \\
\hline 4 & 914023 & $1.6 \pm 0.2$ & $5.42 \pm 0.52$ & $5.18 \pm 0.50$ & $1.63 \pm 1.56$ \\
\hline 5 & 255751 & $-1.5 \pm 1.9$ & $-1.47 \pm 1.84$ & $-1.46 \pm 1.84$ & $-0.05 \pm 0.46$ \\
\hline 6 & 443836 & $-1.3 \pm 1.8$ & $-2.25 \pm 3.09$ & $-2.33 \pm 3.20$ & $0.66 \pm 0.81$ \\
\hline All basins & 2343231 & $0.3 \pm 0.5$ & $2.90 \pm 4.23$ & $2.90 \pm 4.23$ & $5.24 \pm 2.03$ \\
\hline The entire study area & 2427820 & $0.3 \pm 0.7$ & $3.16 \pm 7.03$ & $3.16 \pm 7.02$ & $7.66 \pm 5.91$ \\
\hline
\end{tabular}


a

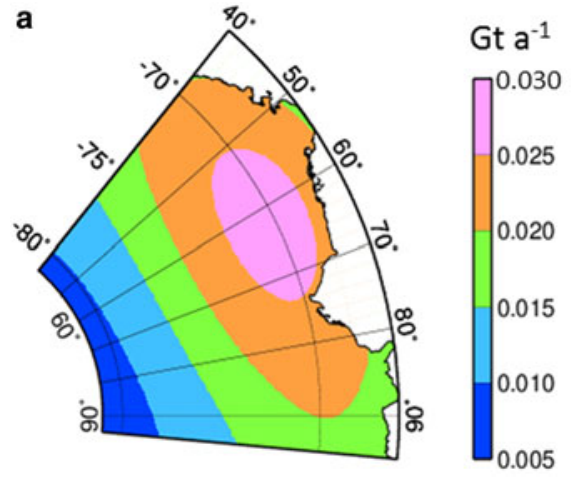

b

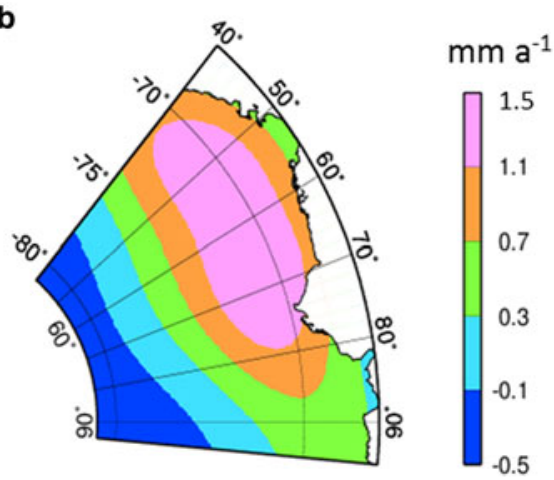

Fig. 5. Spatial distribution of GIA corrections based on the IJ05 R2 model: (a) Mass correction $\left(\mathrm{Gt} \mathrm{a}^{-1}\right)$ integrated at a resolution of $1^{\circ} \times 1^{\circ}$. (b) Elevation correction (uplift) $\left(\mathrm{mm} \mathrm{a}^{-1}\right)$.

others, 1989; Slobbe and others, 2008). The amount of data and the spatial coverage are generally low when only crossover ICESat points are used. Therefore, we use repeated-track points to improve the spatial and temporal coverage. However, this method introduces uncertainties because the points are not located exactly in the same locations. Earlier methods used slope information in an external digital terrain model (DTM) to project ICESat points from one track to another and then compute elevation corrections. By doing so, errors in the DTM are propagated to the estimated elevation changes. An improved technique is to project the ICESat points of different tracks using the slope information from other ICESat points in the neighborhood instead of from an external DTM. This technique takes advantage of updated elevation/slope information of the same quality as the altimetric data (Schutz and others, 2005; Howat and others, 2008; Gunter and others, 2009; Rémy and Parouty, 2009; Moholdt and others, 2010; Liu and others, 2012). Ewert and others (2012) proposed a sophisticated method for mass-balance study in Greenland that involves estimating the elevation trends using repeatedtrack points in an area to fit a polynomial function that contains the elevation trend, the topography of the area and an annual term. The annual term was dropped because of the uncertainty that can be induced by only 2-3 campaigns of ICESat data $\mathrm{a}^{-1}$. This methodology was adopted, modified and implemented to perform the comparative study in LAS, East Antarctica.

The track separation was determined by examining the time flag. Repeated-track points were identified first by constraining the distance between the two tracks within $200 \mathrm{~m}$. At a location on a track, we delineated a box measuring $\sim 500 \mathrm{~m} \times 500 \mathrm{~m}$ in the along- and across-track directions. All repeated-track points in the box were selected for the trend estimation. We employed a simplified spatial/temporal polynomial model based on Ewert and others (2012) and Schenk and Csathó (2012) to characterize the ice surface topography and elevation trend, $h^{\prime}$. For the ith repeated-track point $(i=1,2, \ldots, n)$ in the box with coordinates $\left(x_{i}, y_{i}\right)$, we have

$$
h_{i}=h^{\prime} t_{i}+a_{0}+a_{1} x_{i}+a_{2} y_{i}
$$

where $h_{i}$ is the elevation; $h^{\prime}$ is the trend and is assumed to be constant within the box; and $t_{i}$ is the time when the point was collected, which is referenced to the middle of the study period (1 June, 2006). The first term in Eqn (3) accounts for the temporal change. Because the box size of $500 \mathrm{~m} \times 500 \mathrm{~m}$ is relatively small, the topography of the ice-sheet surface inside the box can be characterized as a plane with the firstorder parameters $a_{0}, a_{1}$ and $a_{2}$. Compared with the secondorder model with ten unknown parameters in Ewert and others (2012), this linear model with four parameters requires a relatively small number of repeated-track points (a minimum of four) in each box. Thus, it avoids a search for additional points in the along-track direction that may cause a biased estimate. This is particularly important for low-latitude areas where the tracks are increasingly separated (Fig. 6a) and the number of repeated-track points in an area is lower (see a later discussion). Once the parameters of $h^{\prime}, a_{0}, a_{1}$ and $a_{2}$ are estimated in a box, the process is repeated for the next box shifted $250 \mathrm{~m}$ from the previous location in the alongtrack direction. When this procedure is performed for all repeated tracks, a map of the elevation change trends in the study area based on the ICESat data can be produced.

The ICESat/GLAS product (GLA12 R633) has 18 campaigns from January 2003 to October 2009 (2-4 campaigns $\mathrm{a}^{-1}$ ). To respond to a sensor problem (Schutz and others, 2005), the last campaign (Campaign 18) was not completed in accordance with its data acquisition plan. Furthermore, Campaign 17 yielded a significant number of empty data areas, based on our data quality examination. Thus, the data from these last two campaigns in 2009 were excluded from this study. To match the GRACE data of 2004-2010, we used 12 ICESat campaigns from 2004 to 2008 to perform a comparative study with the GRACE data for the LAS. The tracks of the ICESat dataset used in the study are illustrated in Figure 6a.

The ICESat points were selected to meet the following five geophysical requirements as proposed and used by Bamber and others (2009a): (1) their attitude control in the metadata is classified as good, (2) only one waveform is detected, (3) the reflectivity of the surface exceeds $10 \%$, (4) the gain is $<200$ and (5) the variance in the waveform from the Gaussian distribution is $<0.03 \mathrm{~V}$. Then, these selected points were projected from the TOPEX ellipsoid to the WGS84 ellipsoid and then from the WGS84 coordinate system to the Universal Polar Stereographic coordinate system.

Due to the error in the range determination from transmitpulse reference-point selection during the 18 campaign periods, there are inadvertent range errors (called the Gaussian-centroid or ' $\mathrm{G}-\mathrm{C}$ ' offset) between ICESat campaign periods. These inter-campaign biases among the campaigns are reported to have a maximum impact of $\pm 10 \mathrm{~cm} \mathrm{a}^{-1}$ on the elevation change estimates (Borsa and others, 2014). In 

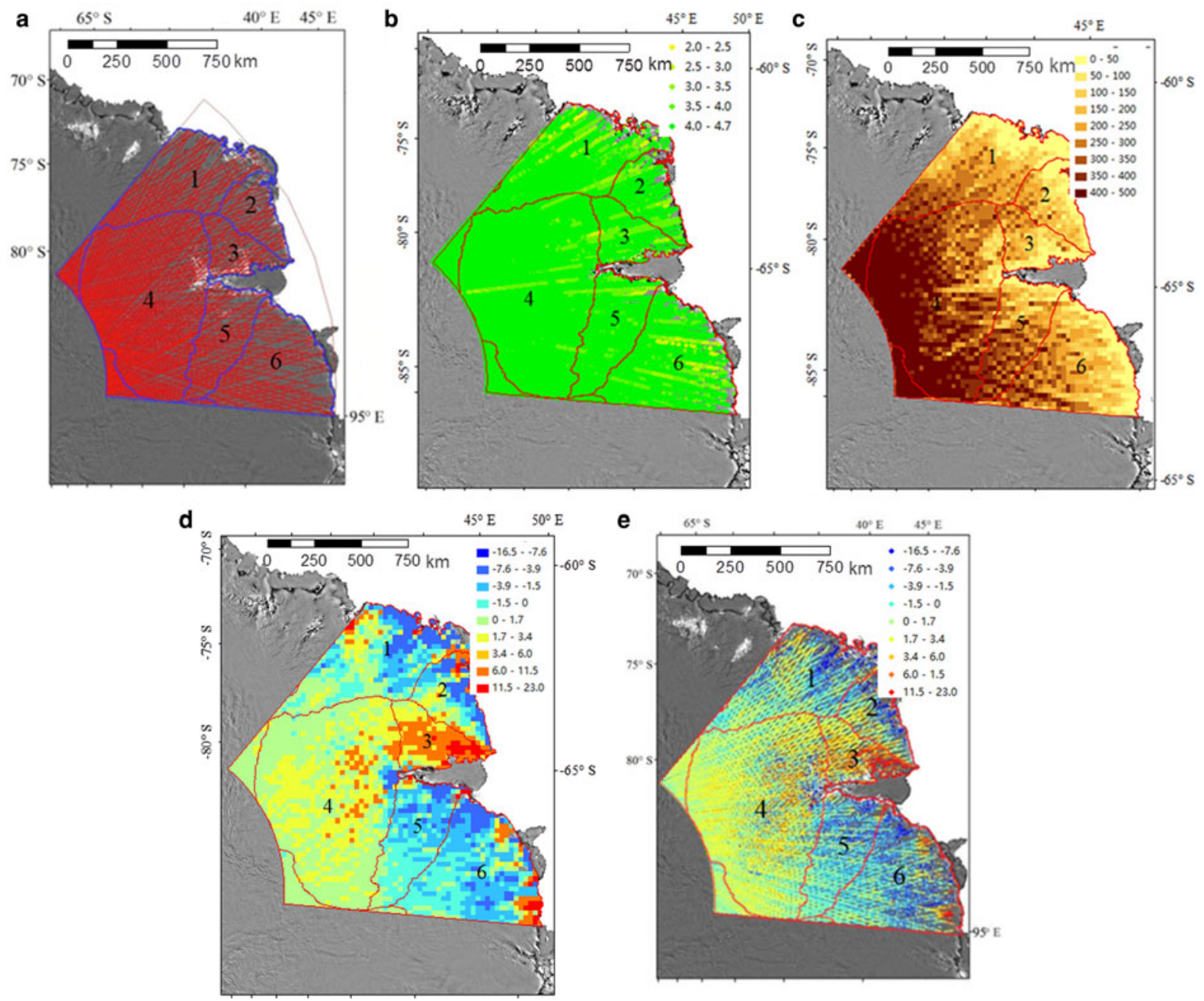

Fig. 6. (a) ICESat tracks in the LAS from February 2004 and October 2008, and major basins in the LAS (Zwally and others, 2012). (b) Number of years covered by all ICESat points in each box. (c) Number of boxes in each cell $(30 \mathrm{~km} \times 30 \mathrm{~km}$ ) of a grid for computation of the trend in the study area and in each basin. (d) Elevation change trend $\left(\mathrm{cm} \mathrm{a}^{-1}\right)$ in each grid cell and (e) elevation change trend $\left(\mathrm{cm} \mathrm{a}^{-1}\right)$ in each box estimated from ICESat data for 2004-2008 after a GIA correction (IJ05 R2 model).

this study, we corrected the inter-campaign biases using files provided by the National Snow and Ice Data Center (NSIDC, 2015). The elevation differences of all ICESat points of 20042008 in the study area before and after the corrections were calculated. Then the mean differences of each campaign were computed, ranging from $\sim-4$ to $6 \mathrm{~cm}$.

A GIA uplift correction calculated using the IJ05 R2 model compensates for the glacial isostatic rebound, which is of the order of -0.5 to $1.5 \mathrm{~mm} \mathrm{a}^{-1}$ in the LAS region (Fig. 5b). This correction was applied to each ICESat point and corresponds to the GIA mass change correction applied in the GRACE data processing.

\subsection{Elevation and mass changes in the LAS estimated from ICESat data}

Overall, the ICESat data provide high-quality spatial and temporal coverage for estimating the elevation trend from 2004 to 2008 . There are 808517 repeated-track points and 736092 boxes in the study area, with an average of ten repeated tracks and 29 repeated-track points in each box. The average temporal coverage of the points in each box is 4.7 a (Fig. 6b) and 99.94\% of the boxes feature a temporal coverage that exceeds 2.5 a. The remaining $0.06 \%$ of the boxes (459 boxes) have a temporal coverage of $2-2.5 \mathrm{a}$ and are in the low-latitude region, where the tracks gradually deviate from one another. Certain ICESat points were eliminated due to the effects of steep slopes in coastal areas. Thus, for the 1166 boxes in the coastal areas $(<50 \mathrm{~km}$ from the coast) the average number of ICESat points in each box is 21. Overall, the spatial and temporal coverage is sufficient to determine the four parameters in Eqn (3).

Figure 6e shows the elevation change trend $\left(\mathrm{cm} \mathrm{a}^{-1}\right)$ in each box estimated from 2004-2008 ICESat data after the GIA correction. To calculate the overall trend in the entire study area and in each basin, we developed an intermediate-level grid with a cell size of $30 \mathrm{~km}$ by $30 \mathrm{~km}$. Figure $6 \mathrm{c}$ illustrates the number of boxes in each grid cell. Within each cell (Fig. 6d), we calculated an average of all trend values of the boxes (Fig. 6e) in the cell. The $30 \mathrm{~km}$ cell size was determined to ensure more than five boxes in each cell for the average computation. Figure $6 \mathrm{c}$ indicates that in the high-latitude inland region, there are sufficient data to calculate the trend in each cell. In the low-latitude coastal areas, the quality of the average trend values may be compromised by the lower number of available original estimates from Eqn (3). We used only cells containing more than five boxes. Finally, we converted each cell's average trend value for elevation change to the corresponding mass change using a firn density of $382 \mathrm{~kg} \mathrm{~m}^{-3}$, which is an 
average of observations at 651 stakes along the CHINARE traverse (see description and discussion below).

The coastal region had a high snow accumulation rate during the study period, as evidenced by the snow stake observations along the CHINARE expedition traverse and the reports of Ding and others $(2011,2013,2015)$. As shown in Figure 6e, a concentrated area of significant elevation changes is located on the west side of the Amery ice shelf, and several similar but smaller areas are spread along the coast east of the ice shelf. The upper interior region (Basin 4) receives less precipitation and consequently has lower positive elevation change rates. However, the basin has the largest area and even with low positive elevation change rates of each box in the basin; these cells collectively give Basin 4 the greatest mass change rate of $5.42 \pm 0.52 \mathrm{Gt}$ $\mathrm{a}^{-1}$ among the analyzed basins in the column of 'Trend from ICESat (I)' in Table 2. The change rates of other basins (Basins 1, 2, 3, 5 and 6) in the same column are not statistically distinguishable from zero. After the estimates of all basins are combined, the overall mass change rate in the LAS estimated from the 2004-2008 ICESat data is $3.16 \pm 7.03 \mathrm{Gt} \mathrm{a}^{-1}$, i.e. not indistinguishable from zero.

Within each box used in the trend estimation, the leastsquares process uses Eqn (3) and the repeated-track points in the box to estimate the four parameters as well as their uncertainties based on the error propagation law (Leick, 2004; Ewert and others, 2012). The uncertainty (standard deviation (SD)) of the elevation of an ICESat repeated-track point, which is also the unit weight SD, $\sigma_{\mathrm{O}}$, is also estimated in each box. Its average from all basins is $8 \mathrm{~cm}$ with a range of $2-16 \mathrm{~cm}$. Similarly, the uncertainty of the trend $h^{\prime}$ in a box, $\sigma_{h^{\prime}}$, can also be calculated. Furthermore, we estimated the uncertainties in the $30 \mathrm{~km} \times 30 \mathrm{~km}$ cells and then in the basins by using the scaled median absolute deviation (MAD) adopted from Ewert and others (2012), which does not require a normal distribution. The detailed explanation of MAD is given in the Supplementary Materials. The estimated elevation trend uncertainties in the basins range from 0.2 to $5.4 \mathrm{~cm} \mathrm{a}^{-1}$, which corresponds to an error in the mass change of 0.52 $2.98 \mathrm{Gt} \mathrm{a}^{-1}$ ('Trend from ICESat (I)' in Table 2). At the basin level, the high-latitude inland region (Basin 4) has a higher density of ICESat points per estimation box (Fig. 6) and the slopes are generally low. Thus, the uncertainty in the elevation change rate for Basin 4 is the lowest $\left(0.2 \mathrm{~cm} \mathrm{a}^{-1}\right)$. In contrast, Basins 2 and 3 are both in lower-latitude areas where the ICESat point density is lower. Furthermore, the steeper slopes in the coastal region of Basin 2 and the steep lateral slope of the Amery ice shelf in Basin 3 are disadvantageous for elevation change estimation. Hence, the uncertainties in the elevation change rates for these two basins are $>5 \mathrm{~cm} \mathrm{a}^{-1}$. Basins 1 , 5 and 6 contain both coastal areas and the interior of the ice sheet, and their uncertainties in the trends are between the two extremes. Finally, the estimated trend for the entire study area is $3.16 \mathrm{Gt} \mathrm{a}^{-1}$, with an error of $\pm 7.03 \mathrm{Gt} \mathrm{a}^{-1}$ based on the uncertainty estimation.

\section{COMPARISON OF THE ICESAT RESULT WITH SNOW STAKE MEASUREMENTS}

\subsection{Determination of firn density for elevation change to mass change conversion}

The in situ observations are along the $1248 \mathrm{~km}$ CHINARE traverse route from Zhongshan station to Dome A (Fig. 1). The data available for this study include snow stake observations (surface firn density from 1999 to 2013 and heights from 2005 to 2008) on stakes at an interval of $10 \mathrm{~km}$ along the traverse. A dataset of firn depth/density measurements in a snow pit $\sim 520 \mathrm{~km}$ from the coast is also available. Although the in situ observations do not represent the entire study area, they do serve limited ground-truth purposes for comparison with the result from the ICESat data. The processing and analysis results of the complete in situ observations from 1997 to 2013, including surface mass balance and snowdrift effects on snow deposition, have been published by Ding and others $(2011,2013,2015)$.

The surface firn density of the upper $0.2 \mathrm{~m}$ was measured during the annual expeditions from 1999 to 2013. The density dataset made available to this study includes only one firn density at each of the 651 stakes along the traverse, which were aggregated from the observations from 1999 to 2013. The data were then smoothed using a $30 \mathrm{~km}$ movingwindow-average filter to remove random noise (Fig. 7). Assuming there were no significant density changes in the study area during the observation period, we used the aggregated firn density data for our study of 2004-2008. The calculated firn density has an average of $382 \mathrm{~kg} \mathrm{~m}^{-3}$, with a SD of $30 \mathrm{~kg} \mathrm{~m}^{-3}$, and ranges from $\sim 300 \mathrm{~kg} \mathrm{~m}^{-3}$ in the Dome A region to $453 \mathrm{~kg} \mathrm{~m}^{-3}$ close to the coast. Generally, the estimation of a long-term imbalance should use a density for the firn and ice column, such as $900 \mathrm{~kg} \mathrm{~m}^{-3}$ for the ERS data of 1992-2001 (Zwally and others, 2005). The present study has a relatively short period of 2004-2008 and we applied this average of the surface firn density measurements for conversion of the ICESat elevation trend to the mass trends in the column of 'Trend from ICESat (I)' in Table 2.

An experiment was also performed to adjust the firn densities of the basins using the in situ density measurements along the CHINARE traverse to deal with spatial variation. First, a linear regression was carried out between the distance to the coast $(x)$ and the density measurements $(y)$ in Figure 7 . A linear function, $y=-0.005 x+400.1$ is estimated (red line, Fig. 7), with a correlation coefficient of $r=0.6$. The density profile shows a decreasing trend from the coast to the high interior.

Second, a centroid for each basin was determined using a GIS (ESRI, 2014) (Fig. 8). In order to facilitate the computation

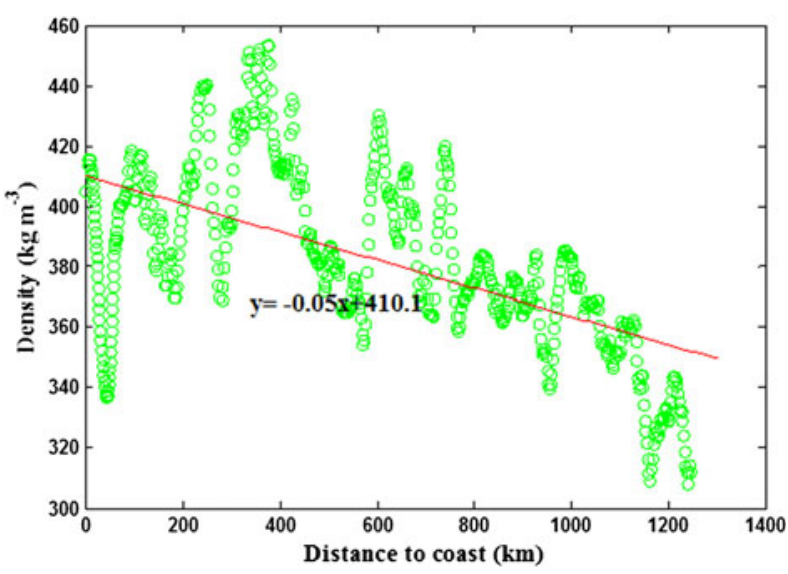

Fig. 7. Aggregated firn density measurements at snow stakes from 1999-2013 along the CHINARE traverse and smoothed using a $30 \mathrm{~km}$ moving-window-average filter. The horizontal axis represents the distance to the coast $(\mathrm{km})$ and the vertical axis shows the firn density $\left(\mathrm{kg} \mathrm{m}^{-3}\right)$. 


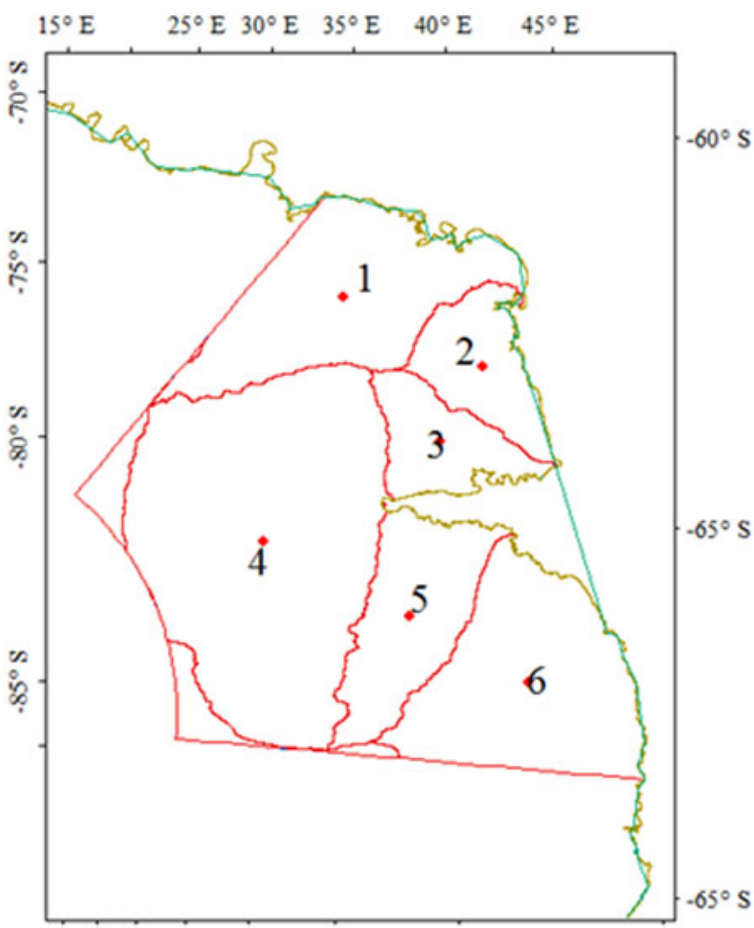

Fig. 8. Centroids of basin boundaries (red dots) and the generalized coast line (green) which were used to adjust the density of each basin.

of the distances from the centroids to the coast, a generalized coast line (green; Fig. 8) was produced by the GIS system based on the detailed MODIS Mosaic of Antarctica (MOA) grounding line (Haran and others, 2014). The calculated distances to the coast for all basins and for the study area are listed in Table 3. Based on the distances the firn density for each basin is then computed using the density/distance regression function and is illustrated in Table 3. Finally, the mass change rates of the basins were recalculated using the new density values and presented in the column, 'Trend from ICESat (II)' in Table 2.

It is observed that the coastal basins (Basins 1, 2, 3 and 6) have their distances to the coast shorter than the half-length of the traverse. Their calculated firn densities are also greater than the average density of $382 \mathrm{~kg} \mathrm{~m}^{-3}$ (last two columns in Table 3). Correspondingly the magnitude of their adjusted mass trends in column, 'Trend from ICESat (II)' increased by 3-6\% compared with these in column, 'Trend from ICESat (I)' in Table 2. In contrast Basins 4 and 5 are farther away from the coast and thus obtained reduced densities in Table 3. Similarly the magnitude of their adjusted mass trends in the column, 'Trend from ICESat (II)' decreased by $5 \%$ for Basin 4 and $1 \%$ for Basin 5. The overall densities and trends of all basins and the study area remained unchanged. Although the trends of the individual basins were adjusted by $<6 \%$, the adjustment was performed based on their proximities to the coast and the in situ density measurements. The adjusted trends in Table 2 were adopted.

\subsection{Comparison of ICESat result with snow stake accumulation measurements}

Surface snow accumulation rate from the snow stake observations along the CHINARE traverse is illustrated as red
Table 3. Firn density recalculated for each basin using an aggregated function from the in situ measurements along the CHINARE traverse

\begin{tabular}{lccc}
\hline Basin & $\begin{array}{c}\text { Distance to } \\
\text { coast } \\
\mathrm{km}\end{array}$ & $\begin{array}{c}\text { Density of } \\
\text { basin } \\
\mathrm{kg} \mathrm{m}^{-3}\end{array}$ & $\begin{array}{c}\text { Ratio (basin } \\
\text { vs average } \\
\text { density) }\end{array}$ \\
\hline 1 & 336 & 394.5 & 1.03 \\
2 & 126 & 404.2 & 1.05 \\
3 & 349 & 393.8 & 1.03 \\
4 & 965 & 365.3 & 0.96 \\
5 & 626 & 381.0 & 0.98 \\
6 & 315 & 395.4 & 1.03 \\
All basins & 611 & 382 & 1 \\
The entire study & 611 & 382 & 1 \\
area & & & \\
\hline
\end{tabular}

dots in Figure 9. The smoothed accumulation rate (light blue curve) was produced by filtering with a $30 \mathrm{~km}$ moving-window average, which can be considered as the surface height change (SHC) rate. The mean difference between the raw stake data and the smoothed curve is $-0.05 \mathrm{~cm} \mathrm{a}^{-1}$ with a SD of $11 \mathrm{~cm} \mathrm{a}{ }^{-1}$. A detailed surface mass-balance analysis with respect to local and regional terrain using snow stake observations from a longer period is provided by Ding and others $(2011,2015)$. The rate of SEC from ICESat data after the GIA correction was extracted from the $30 \mathrm{~km}$ resolution ICESat 2004-2008 trend map (Fig. 6d) and is represented by the dark curve line in Figure 9. In the inland section of relatively flat, high-elevation terrain located $220-1248 \mathrm{~km}$ from the coast, the SHC rate has average, $15 \mathrm{~cm} \mathrm{a}^{-1}$ with SD, $6 \mathrm{~cm} \mathrm{a}^{-1}$ and the SEC rate from the ICESat data has average, $1 \mathrm{~cm} \mathrm{a}^{-1}$ with $S D$, $2 \mathrm{~cm} \mathrm{a}^{-1}$. Thus, their difference is $14 \mathrm{~cm} \mathrm{a}^{-1}$. In the coastal section, i.e. from the coast (Zhongshan Station) to $220 \mathrm{~km}$ inland, where the topography changes rapidly from near sea level to an elevation of $\sim 2100 \mathrm{~m}$, the SHC rate is highest with average, $37 \mathrm{~cm} \mathrm{a}^{-1}$ and $\mathrm{SD}, 7 \mathrm{~cm} \mathrm{a}^{-1}$. The SEC rate from the ICESat data has a significantly contrasting trend, i.e. an average, $-6 \mathrm{~cm} \mathrm{a}^{-1}$ with $\mathrm{SD}, 0.85 \mathrm{~cm} \mathrm{a}^{-1}$. This results in a difference of $43 \mathrm{~cm} \mathrm{a}^{-1}$ in the coastal section and should be investigated further.

In general, a relationship exists between the measured SEC and the local mass-balance components (Csatho and others, 2014; Li and Zwally, 2011):

$$
\mathrm{SEC}+\mathrm{GIA} \_ \text {Corr }=\mathrm{SHC}+\text { Singk_Corr }+ \text { DVEC } .
$$

The GIA correction (uplift), GIA_Corr $\left(\mathrm{mm} \mathrm{a}^{-1}\right)$, is shown in Figure $5 \mathrm{~b}$. The $\mathrm{SHC}$ represents the surface mass balance and is computed from the stake observations, which contain the effects of the summed changes that have occurred above the stake bottom, such as precipitation, sublimation, meltwater, runoff and others. Singk_Corr corrects for the sinkage of the stakes due to snow compaction. Finally, DVEC is the vertical elevation change below the stake bottom that should represent the dynamic thickness change. Equation (4) can be rewritten as

$$
\text { SHC - SEC - GIA_Corr }=- \text { Singk_Corr }- \text { DVEC. }
$$

The vertical surface difference after the GIA correction (SHC - SEC - GIA_Corr) can be calculated from the processed snow stakes and ICESat results in Figure 9 and is 


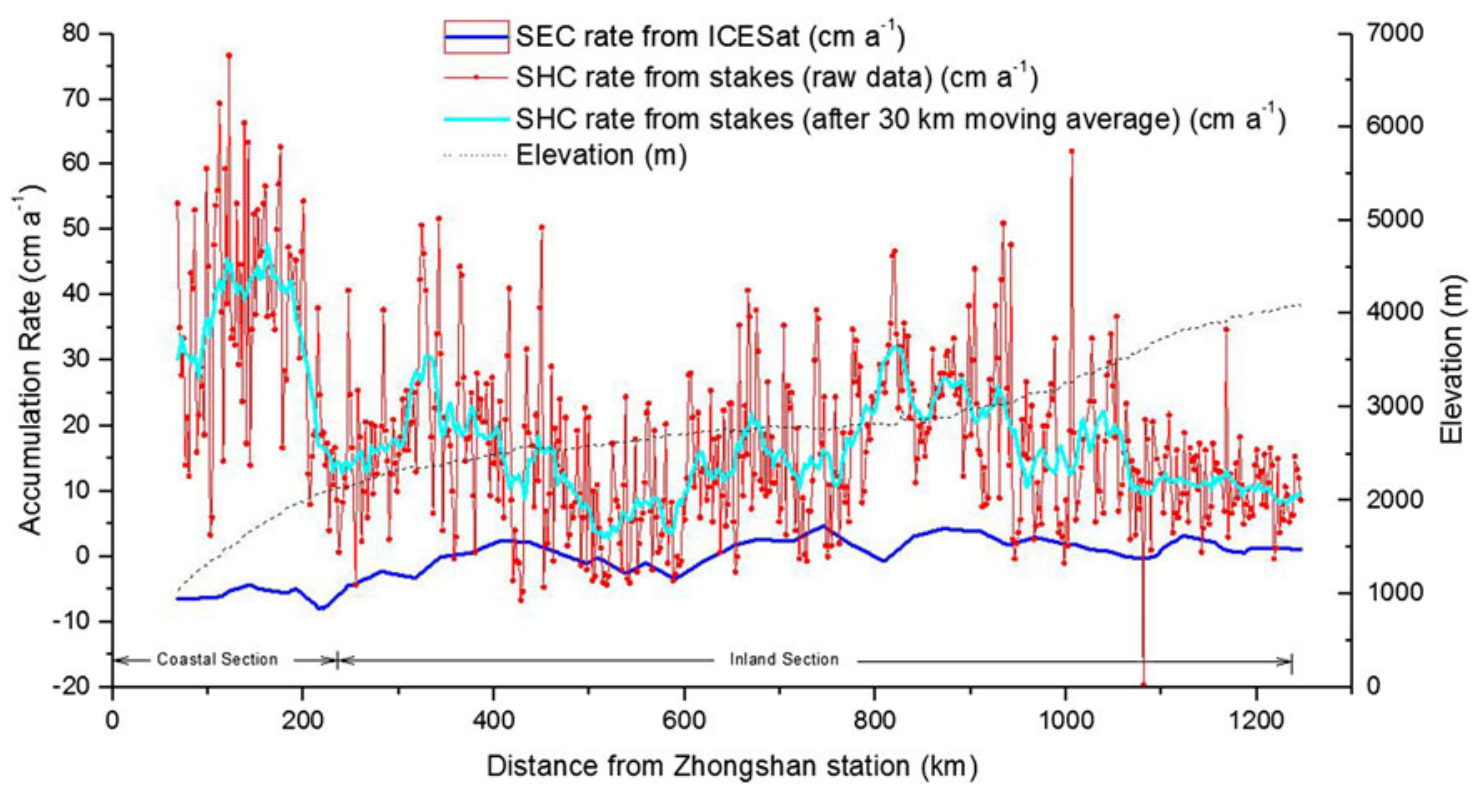

Fig. 9. Snow accumulation rate from 2005 to 2008 snow stake observations (red dots), smoothed snow accumulation rate after filtering with a $30 \mathrm{~km}$ moving-window average (light blue), SEC rate from 2004 to 2008 ICESat data after GIA correction (dark blue), and elevation profile along the CHINARE traverse from Zhang and others (2008).

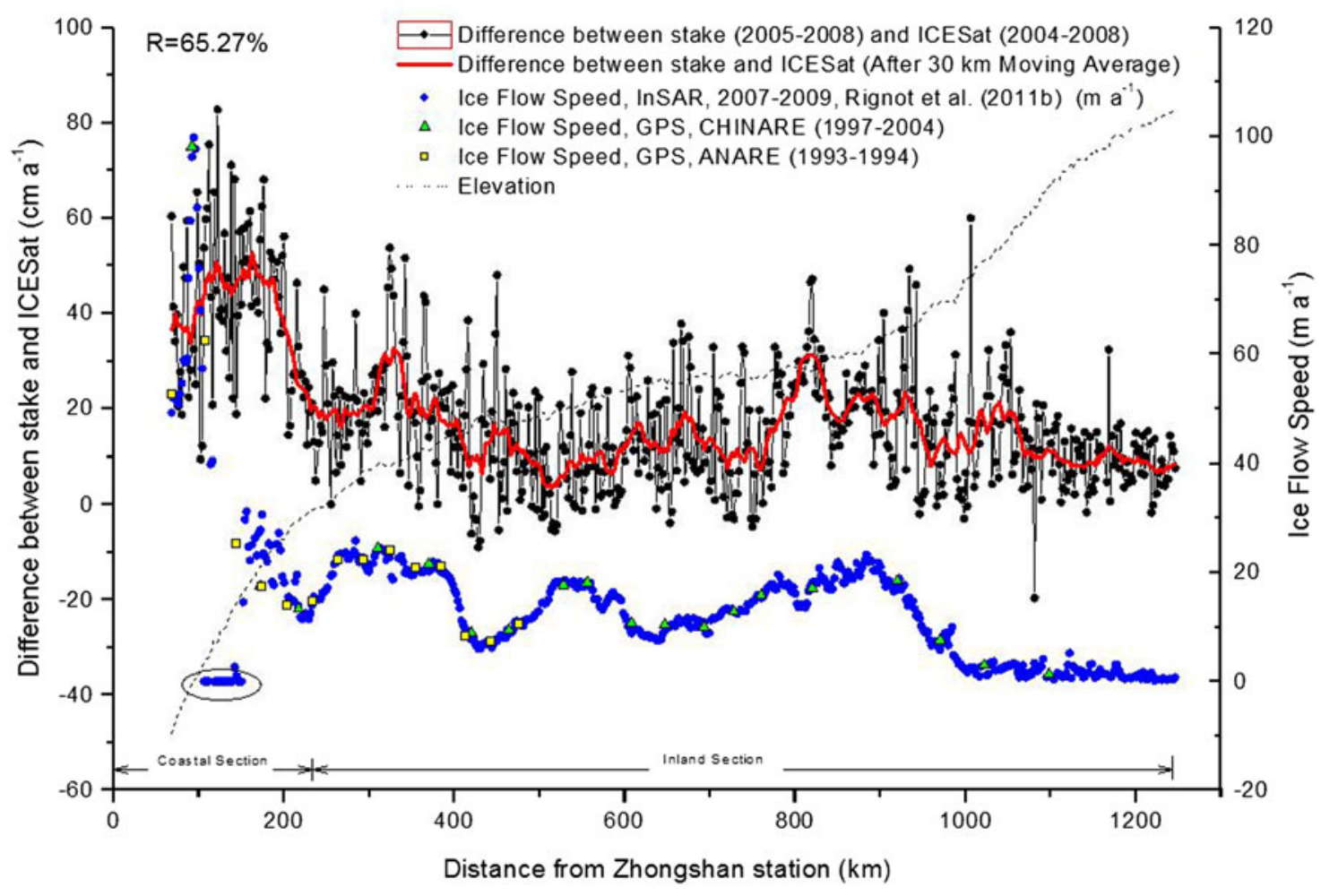

Fig. 10. Differences between the 2005-2008 snow stakes and 2004-2008 ICESat results at the stake locations (black dots), the $30 \mathrm{~km}$ movingwindow average of the differences (red), and the ice flow speeds (blue dots, green triangles and yellow squares) along the CHINARE traverse.

illustrated in Figure 10, where the black dots represent the differences between the snow stakes and the ICESat results at the stake locations. The red curve is the $30 \mathrm{~km}$ movingwindow average of the differences.

The comparison between the SHC and SEC rates only makes sense if the background sinking of the stakes due to densification below the stake base and vertical flow of the ice, which are expressed on the right-hand side of Eqn (5), are taken into account (Dibb and Fahnestock, 2004). An effort was made to compute the sinkage corrections according to Takahashi and Kameda (2007) and Eisen and others (2008) using the available depth/density data at the only snow pit $520 \mathrm{~km}$ from the coast. However, this effort resulted in unreasonable corrections in the Dome A region. Thus, the sinkage correction was not performed in this study. Ding and others (2015) indicated that the uncertainty of surface mass balance caused by densification in this region is $\sim-1.9 \%$ at $296 \mathrm{~km}$ from the coast (coastal section), $-3.5 \%$ at $800 \mathrm{~km}$ 
(inland section) from the coast and $0 \%$ at Dome A for a 5 a snow layer. Given the SHC averages and the above uncertainty values, the estimated uncertainty of the average SHC rates may be $-0.6 \mathrm{~cm} \mathrm{a}^{-1}$ in the coastal section, $-0.5 \mathrm{~cm} \mathrm{a}^{-1}$ in the inland section and zero at Dome A. Therefore, these values should not play a major role in the differences between the rates derived from the stakes and the ICESat data, which are on average $31 \mathrm{~cm} \mathrm{a}^{-1}$ in the coastal section and $12 \mathrm{~cm} \mathrm{a}^{-1}$ in the inland section.

We do not have direct information on the dynamic thickness changes along the traverse, i.e. DVEC in Eqn (5). However, two sources of the ice flow speed are available. At each stake location, the horizontal ice flow speed along the traverse (blue dots; Fig. 10) was extracted from an ice flow-speed map of Antarctica from 2007 to 2009, which was estimated from satellite SAR and InSAR observations (Rignot and others, 2011b). The zero speed dots that are circled in the coastal section appear to be inconsistent with the rest of the entire speed curve based on a visual inspection of the speed map and optical satellite images. A set of GPS points along the same traverse is also available: 19 CHINARE points were measured in 1997-2004 (green triangles; Fig. 10) and 13 ANARE points were measured in 19931994 (yellow squares; Fig. 10) (Manson and others, 2000; Zhang and others, 2008). The ice flow-speed values of the GPS points and the speed map agree in the inland section with an average difference, $0.4 \mathrm{~m} \mathrm{a}^{-1}$, SD of $1.2 \mathrm{~m} \mathrm{a}^{-1}$. A greater difference exists in the coastal section, with average difference, $6.4 \mathrm{~m} \mathrm{a}^{-1}$, SD $26.7 \mathrm{~m} \mathrm{a}^{-1}$. The complete profile of the ice flow speed consists of the speed data from the InSAR ice flow-speed map and the GPS speed observations of the CHINARE and ANARE expeditions. The combined ice flow-speed profile is also filtered with a $30 \mathrm{~km}$ movingaverage filter.

In principle, dynamic thickening/thinning of the ice sheet is not directly related to the horizontal ice velocity, but to the acceleration, which is not available in this study. There may be a correlation between horizontal ice velocities and accelerations, and thus between horizontal ice velocities and dynamic thinning. Such a correlation may imply causation. The ice flow-speed profile (horizontal) and the curve of the differences between the stake and ICESat observations in Figure 10 are correlated $(r=0.65)$. In the coastal section, the location around the highest speeds corresponds with an upstream area of a tributary ice flow into the Amery ice shelf, as shown on the ice flow-speed map (Rignot and others, 2011b). This relatively high level of correlation indicates that dynamic thinning may explain the significant difference between the high accumulation measurements from the snow stakes and the decreased trend from the ICESat data in the coastal section.

Although there is no in situ measurement coverage of accumulation in the entire coastal section of the study area, a correlation between the ICESat trend and ice flow speed was performed. First, a coastal zone of $250 \mathrm{~km}$ from the grounding line/coastline was defined, which is in the grounded portion of the ice sheet in the study area. Then the ICESat trend of 2004-2008 in the $30 \mathrm{~km} \times 30 \mathrm{~km}$ grid (Fig. 6d) was clipped using the $250 \mathrm{~km}$ coastal zone (Fig. 11a). The ice flow speed in the coastal zone was resampled at $30 \mathrm{~km} \times 30 \mathrm{~km}$ cells from the ice speed map in Rignot and others (2011b). A correlation coefficient between the ICESat trend and ice flow speed, $\rho_{\text {Speed }_{i} \text {, was }}$ calculated using the ice flow-speed cells with values greater than 'Speed' $i$ and the corresponding ICESat trend cells. Figure $11 \mathrm{~b}$ plots the correlation coefficients for ice flow speed from 0 to $500 \mathrm{~m} \mathrm{a}^{-1}$. There is no significant correlation until Speed $_{i}=222 \mathrm{~m} \mathrm{a}^{-1}$; after that the correlation coefficient is $>0.65$ and reached 1 at about $340 \mathrm{~m} \mathrm{a}^{-1}$ (Fig. $11 \mathrm{~b}$ ). We can observe that in Figure 11a the negative trend cells (light to dark blue dots) appear mostly near and along the ice flow lines (thin black) where the ice flow speed is high, except for some areas in Basin 3. This spatial correlation pattern may suggest that the dynamic ice thickness changes caused by the ice flows may have exceed the high snow accumulation rates in these places of the coastal section.

\section{RECONCILED GRACE/ICESAT ESTIMATE AND SPATIAL ANALYSIS}

The GIA effect was corrected in both GRACE and ICESat results. The SEC derived from the ICESat data reflect the surface mass balance (SHC), firn compaction (Singk_Corr) and ice dynamic changes (DVEC) in Eqn (4) when it is applied to the entire LAS study area. The rate of firn compaction is associated with elevation changes, but it does not involve changes in mass (Zwally and Li, 2002). As shown in the previous section, the uncertainty caused by firn compaction in this study is not significant (Ding and others, 2015). If it is assumed that the vertical ice velocity (ice
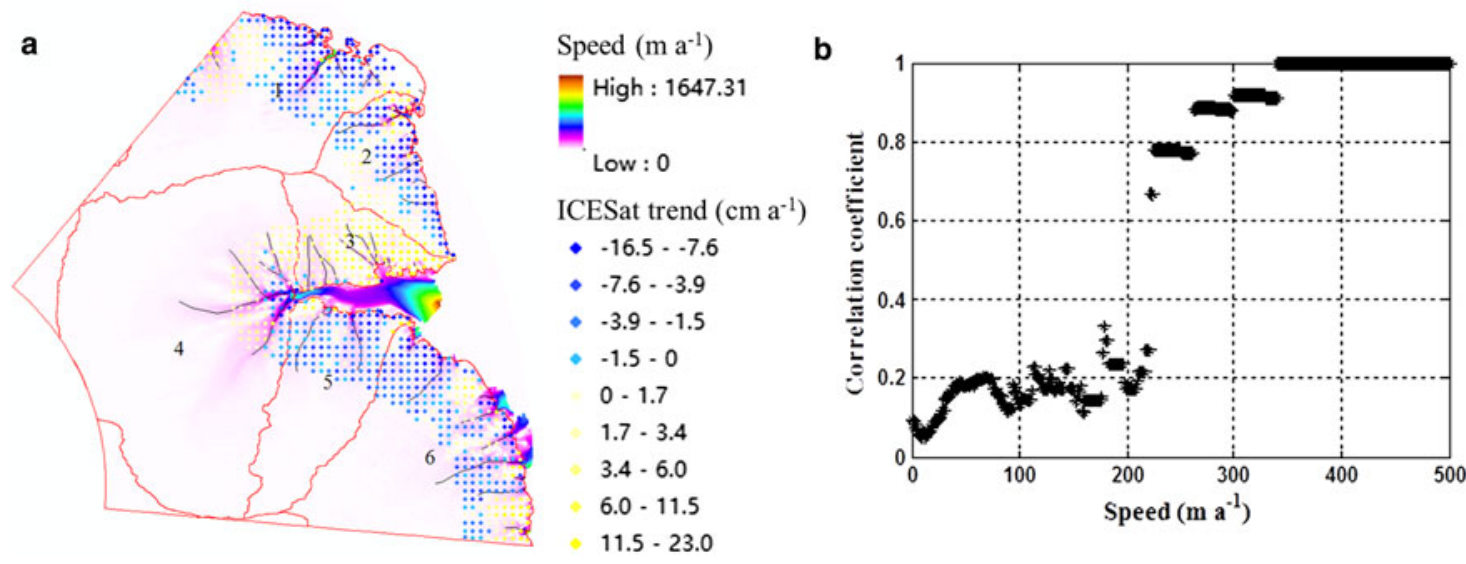

Fig. 11. (a) Three layers of information prepared for correlation analysis: Elevation trend of 2004-2008 in a $30 \mathrm{~km} \times 30 \mathrm{~km}$ grid derived from the ICESat data and clipped inside a $250 \mathrm{~km}$ coastal zone, ice flow speed by Rignot and others (2011b), and generalized ice flow lines (black) from Liu and others (2015). (b) Correlation between the ice speed and ICESat trend estimates. 
flow) is in balance with the long-term average accumulation rate, the elevation changes can be attributed to accumulation anomalies over the observed period. Thus, although elevation change rates are significant in some local areas (Figs $6 \mathrm{e}, 11 \mathrm{a})$, the overall ICESat trend of $0.3 \pm 0.7 \mathrm{~cm} \mathrm{a}^{-1}$ from 2004 to 2008 in the LAS region (Table 2) is statistically indistinguishable from zero.

The mass change estimated using the GRACE observations represents the overall change, including the surface mass change, changes caused by subglacier activities and mass changes beneath the ice sheet. The mass change rate of $7.66 \pm 5.91 \mathrm{Gta}^{-1}$ in the LAS from the GRACE data (Table 2) is not significantly different from the rate of $3.16 \pm 7.03 \mathrm{Gt} \mathrm{a}^{-1}$ from the ICESat data, given their uncertainties $(1 \sigma)$. We combined the two results from the GRACE and ICESat data to achieve a reconciled trend in the LAS from 2004 to 2008 by using the arithmetic mean, $5.41 \mathrm{Gt}$ $\mathrm{yr}^{-1}$ and the uncertainty of the arithmetic mean $(1 \sigma ; \mathrm{S} 3$ in the Supplementary Material), $4.59 \mathrm{Gt} \mathrm{a}^{-1}$.

With regard to the recent mass balance in the LAS summarized in Table 1, the estimates of 1992-2003 from the ERS data by Zwally and others (2005) and Wingham and others (2006b) are contradictive and we cannot reach a conclusion based on the discussion in the introduction section. The same applies to the opposite estimates of 2000 using the input/output method of Rignot and others (2008) and Yu and others (2010). However, both LAS-specific research efforts using in situ measurements by Ren and others (2002) (though without an uncertainty specification) and $\mathrm{Yu}$ and others (2010) resulted in positive estimates. Furthermore, the results of both earlier GRACE studies showed positive trends, $36 \pm 11 \mathrm{Gt} \mathrm{a}^{-1}$ from 2002 to 2010 by King and others (2012) and $35 \pm 8 \mathrm{Gt} \mathrm{a}^{-1}$ from 2003 to 2012 by Sasgen and others (2013). In comparison with the estimate of $7.66 \pm 5.91 \mathrm{Gt} \mathrm{a}^{-1}$ of 2004-2008 from the GRACE data in this study, the difference in the magnitude may be attributed mainly to the different integration lengths (8-10 a vs $4.75 \mathrm{a})$. The long-term trend is advantageous in eliminating or reducing the effect of multiyear annual changes and short-term anomalies. On the other hand, the GRACE estimate of 2004-2008 is sufficient to capture a shorter term trend of mass changes in the LAS, which agrees with the estimate of the same period from the ICESat data and in situ CHINARE measurements. The reconciled trend in the LAS of 2004-2008 from both GRACE and ICESat estimates, $5.41 \pm 4.59 \mathrm{Gt} \mathrm{a}^{-1}$, is also in line with another short-term estimate of 2010-2013 from the CryoSat-2 data, $2 \pm 18 \mathrm{Gt}$ $\mathrm{a}^{-1}$, by McMillan and others (2014).

Overall, we suggest a balanced to slightly positive mass balance in the LAS from 2004 to 2008, given the level of the uncertainty. The LAS may have a positive mass balance since 1994 (Ren and others, 2002); a definite positive trend has existed at least since 2002 (King and others, 2012; Sasgen and others, 2013); and this positive change rate may have slowed in recent years (this study; McMillan and others, 2014).

To compare the spatial variations, Figure 12 presents the mass change rates of ICESat and GRACE in a grid with a cell size of $30 \mathrm{~km} \times 30 \mathrm{~km}$ where the ICESat result was converted from the aggregated elevation trend map (Fig. 6d), whereas the GRACE result was interpolated from a grid with a much larger cell size of $1^{\circ} \times 1^{\circ}$. The ICESat trend map shows a higher level of spatial detail. The GRACE trend map appears to be a highly spatially aliased version
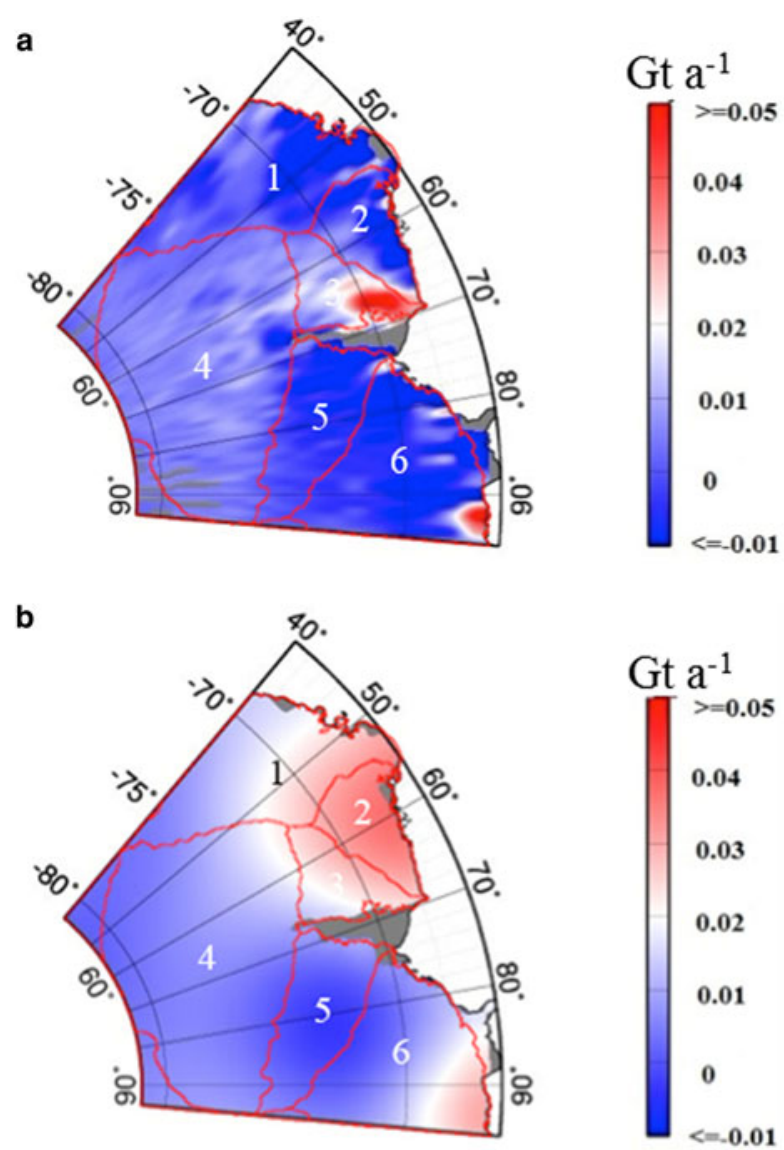

Fig. 12. Trend maps for the LAS from 2004 to $2008\left(\mathrm{Gt} \mathrm{a}^{-1}\right.$; resolution $30 \mathrm{~km} \times 30 \mathrm{~km}$ ): (a) Mass change rate from ICESat data and (b) corresponding rate from GRACE data.

of the ICESat trends. The relatively low level of positive rates across the vast high-latitude inland area (Basin 4) is consistently shown in both the ICESat and GRACE results. Correspondingly, Basin 4 has the highest trends from both the ICESat and GRACE data (Table 2). The negative trend of Basin 5 appears also consistently in both maps.

The high change rates in both datasets occur in the coastal areas (Fig. 12). However, these rates are spread broadly across more basins in the GRACE result than in the ICESat result. For example, the red area of the high ICESat positive trend in Basin 6 (Fig. 12a) was detected by relatively densely populated ICESat points (Fig. 6). In the GRACE map (Fig. 12b), the corresponding high positive rates are centered at about the same location, but across a larger region $(\sim 300 \mathrm{~km} \times$ $440 \mathrm{~km})$. Although the original GRACE points were integrated at a resolution of $1^{\circ} \times 1^{\circ}$, which was output at a higher spatial resolution in this high latitude region (Fig. S2; Supplementary Material), at a global level GRACE can resolve features of $\sim 400 \mathrm{~km}$ to $600 \mathrm{~km}$ (Tapley and others, 2004b). Thus, the area in the GRACE map $(\sim 300 \mathrm{~km} \times 440 \mathrm{~km})$ would just be resolvable. The reddish color shades (high positive trend values) of the $30 \mathrm{~km} \times 30 \mathrm{~km}$ cells in the expanded area are mainly attributed to the resolution of the GRACE solution and the effect of the interpolation. Furthermore, the high ICESat positive trends in Basin 3 occupy a concentrated area (Fig. 12a). However, its center is shifted by $\sim 400 \mathrm{~km}$ to Basin 2 in the GRACE map and the high positive trends spread across a much larger area. The expansion of the area can also be mainly explained by the low resolution of the 
GRACE solution and the interpolation effect. But the shift of the areal center may indicate that the data are affected by so-called 'internal leakage errors' (King and others, 2012; Memin and others, 2014), which account for effects of the leakage from neighboring basins. A quantitative confirmation and analysis of this effect are beyond the scope of this study and will be our future research. Overall these cross-basin spatial variations may be caused by the resolution difference between the ICESat and GRACE data, the interpolation effect and the internal leakage errors, among others. Combined with the uncertainty in the firn density, these effects further caused the disagreement between the GRACE and ICESat results in Basins 1, 2, 3 and 6 (Table 2).

\section{CONCLUSIONS AND DISCUSSIONS}

This paper presents the results of a comprehensive study of the regional mass changes from 2004 to 2008 in the LAS, Antarctica, using GRACE, ICESat and in situ CHINARE data. A survey and analysis of the recent research results in the LAS was performed. The present results were achieved by using both satellite remote sensing data and regional in situ measurements, and contribute to the understanding of the long-term mass balance and quantification of the trend in the recent years in the study area. The estimation of the ICESat mass change rates benefitted from the density measurements along the CHINARE traverse and a spatial density adjustment method for reducing the effect of spatial density variations. The CHINARE surface accumulation measurements and surface ice flow-speed data were analyzed jointly with the ICESat elevation changes to investigate the regional mass-balance details. Finally, the mass change rate of 2004-2008 in the LAS was determined by a reconciled GRACE/ICESat estimation. The following are the discussions and conclusions of this study:

(1) Uncertainties in the firn density have been one of the major error sources for mass change estimation from altimetry data. The surface firn density measurements along the CHINARE traverse showed a variation from $\sim 300 \mathrm{~kg} \mathrm{~m}^{-3}$ in the Dome A region to $453 \mathrm{~kg} \mathrm{~m}^{-3}$ at the coast. The average of $382 \mathrm{~kg} \mathrm{~m}^{-3}$ was used for the ICESat mass trend estimate during the period of 20042008, which was further improved by a spatial density adjustment method for reducing the effect of spatial density variations in the entire study area. The achieved regional ICESat mass trend, $3.16 \pm 7.03 \mathrm{Gt} \mathrm{a}^{-1}$, agreed with that derived from the overlapping GRACE data, $7.66 \pm 5.91 \mathrm{Gt} \mathrm{a}^{-1}$, given their uncertainties.

(2) Along the CHINARE traverse the ICESat elevation change rate was closer to the snow stake surface change rate with an average difference of $14 \mathrm{~cm} \mathrm{a}^{-1}$ in the inland section (220-1248 km from the coast). The same difference rose to $43 \mathrm{~cm} \mathrm{a}^{-1}$ in the coastal section $(0-220 \mathrm{~km}$ from the coast). A correlation coefficient of 0.65 is achieved between the ice flow speed and the difference between the snow stake and ICESat results along the traverse. A further analysis investigated the correlation between the ICESat trend and ice flow speed in the coastal region of the entire LAS. The correlation coefficient is $>0.65$ if the flow speed $>222 \mathrm{~m} \mathrm{a}^{-1}$ and 1 above $\sim 340 \mathrm{~m} \mathrm{a}^{-1}$. The above result suggests that during the study period the dynamic ice flow discharge surpassed the snow accumulation in many high flow-speed glacier areas along the coast.
(3) At the basin level, both the ICESat and GRACE results agree in places where significant changes exist and the areas are greater than the feature size that the GRACE solutions can resolve. For example, the vast high-elevation inland region receives less precipitation and, thus, has a low level of positive elevation change rate in each cell. Due to its large area, Basin 4 exhibits the greatest mass change rates from both GRACE and ICESat data among the basins. On the other hand, the GRACE trend map appears to be a highly spatially aliased version of the ICESat trends. The largest positive mass changes occur in the coastal region. But there are differences in their areal sizes and a shift of centers. The difference in areal sizes can be attributed to the different resolutions and effect of interpolation; the shift of the areal centers may be caused by so called 'internal leakage errors', which needs to be further researched. These crossbasin discrepancies in spatial variations further caused the basin level disagreements between the GRACE and ICESat estimates in Basins 1, 2, 3 and 6.

(4) Overall, the reconciled trend in the LAS of 2004-2008 from both GRACE and ICESat estimates is $5.41 \pm 4.59 \mathrm{Gt} \mathrm{a}^{-1}$. With regard to the recent mass balance in the LAS, a positive mass balance may have occurred at a rate of $17 \mathrm{Gt} \mathrm{a}^{-1}$ (no uncertainty given) during the period of 1994-1999 based on an estimate using both CHINARE and ANARE in situ measurements (Ren and others, 2002). The positive trends of $36 \pm 11 \mathrm{Gt} \mathrm{a}^{-1}$ from 2002 to 2010 and $35 \pm 8 \mathrm{Gt} \mathrm{a}^{-1}$ from 2003 to 2012 in the LAS were derived from the results by King and others (2012) and Sasgen and others (2013) respectively; these estimates showed a long-term trend after removing the effect of multiyear annual changes and short-term anomalies. In this study, the reconciled trend of $5.41 \pm 4.59 \mathrm{Gt} \mathrm{a}^{-1}$ from 2004 to 2008 was estimated using the GRACE, ICESat and CHINARE in situ data; this estimate indicated a shorter-term trend of balanced to slightly positive mass changes in the LAS. This positive mass trend in the LAS may have slowed down recently based on another shorter-term estimate of $2 \pm 18 \mathrm{Gta}^{-1}$ from 2010 to 2013 that was derived from the CryoSat-2 result by McMillan and others (2014).

\section{SUPPLEMENTARY MATERIAL}

The supplementary material for this article can be found at http://dx.doi.org/10.1017/jog.2016.76.

\section{ACKNOWLEDGEMENTS}

Constructive comments and suggestions by editors and two reviewers are greatly appreciated. Data from National Snow and Ice Data Center (NSIDC), University of Colorado, Center for Space Research (CSR), University of Texas at Austin, CHINARE and ANARE programs, and Polar Research Institute of China are also greatly appreciated. The work described in the paper was substantially supported by the National Basic Research Program of China - 973 Program (Project Nos 2012CB957701, 2012CB957702), the National Natural Science Foundation of China (Project Nos 41201426, 41325005, 41571407), the Shanghai Rising-Star Program (Project No. 15QA1403700) and the Fundamental Research Funds for the Central Universities. 


\section{REFERENCES}

Bamber JL, Gomez-Dans JL and Griggs JA (2009a) A new $1 \mathrm{~km}$ digital elevation model of the Antarctic derived from combined satellite radar and laser data - Part 1: data and methods. Cryosphere, 3, 101-111

Bamber JL, Riva REM, Vermeersen BLA and LeBroq AM (2009b) Reassessment of the potential sea-level rise from a collapse of the West Antarctic Ice Sheet. Science, 324(5929), 901-903 (doi: 10.1126/science.1169335)

Barletta V, Sørensen L and Forsberg R (2013) Scatter of mass changes at basin scale for Greenland and Antarctica. Cryosphere, 7, 1411-1432 (doi: 10.5194/tc-7-1411-2013)

Baur O, Kuhn M and Featherstone W (2013) Continental mass change from GRACE over 2002-2011 and its impact on sea level. J. Geodesy, 87(2), 117-125 (doi: 10.1007/s00190-0120583-2)

Bettadpur S (2007a) CSR level-2 processing standards document for product release 04. Report JPL 327-742, GRACE. The GRACE Project, Center For Space Research, University of Texas at Austin, Austin, Tex., USA, 327-742

Bettadpur S (2007b) Product specification document. Report JPL 327-720. Center for Space Research, University of Texas at Austin, Austin, Tex., USA

Bettadpur S and The CSR Level-2 Team (2012) Insights into the Earth System mass variability from CSR-RL05 GRACE gravity fields. In Paper Presented at European Geosciences Union General Assembly 2012, Vienna, Austria.

Borsa AA, Moholdt G, Fricker HA and Brunt KM (2014) A range correction for ICESat and its potential impact on ice sheet mass balance studies. Cryosphere, 8, 345-357 (doi: 10.5194/tc-8345-2014)

Cazenave A and Llovel W (2010) Contemporary sea level rise. Annu. Rev. Mar. Sci., 2, 145-173 (doi: 10.1146/annurevmarine-120308-081105)

Chen JL, Wilson CR, Blankenship DD and Tapley BD (2006) Antarctic mass rates from GRACE. Geophys. Res. Lett., 33, L11502 (doi: 10.1029/2006GL026369)

Chen JL, Wilson CR, Tapley BD and Grand S (2007) GRACE detects coseismic and postseismic deformation from the SumatraAndaman earthquake. Geophys. Res. Lett., 34, L13302 (doi: 10.1029/2007GL030356)

Chen JL, Wilson CR, Tapley BD, Blankenship D and Young D (2008) Antarctic regional ice loss rates from GRACE. Earth Planet. Sci. Lett., 266(1), 140-148 (doi: 10.1016/j.epsl.2007.10.057)

Chen JL, Wilson CR, Blankenship D and Tapley BD (2009) Accelerated Antarctic ice loss from satellite gravity measurements. Nat. Geosci., 2(12), 859-862 (doi: 10.1038/ngeo694)

Chen QJ and 6 others (2015a) Monthly gravity field models derived from GRACE Level 1B data using a modified short-arc approach. J. Geophys. Res., 120(3), 1804-1819 (doi: 10.1002/2014JB011470)

Chen QJ, Shen YZ, Zhang XF, Chen W and Hsu HZ (2015b) TongjiGRACE01: a GRACE-only static gravity field model recovered from GRACE Level-1B data using modified short arc approach. Adv. Space Res., 56(5), 941-951 (doi: 10.1016/j.asr.2015.05.034)

Csatho BM and 9 others (2014) Laser altimetry reveals complex pattern of Greenland Ice Sheet dynamics. Proc. Natl. Acad. Sci. USA, 111(52), 18478-18483 (doi: 10.1073/pnas.1411680112)

Davis $\mathrm{CH}$ (1992) Satellite radar altimetry. IEEE Trans. Microw. Theory Tech., 40(6), 1070-1076 (doi: 10.1109/22.141337)

Dibb JE and Fahnestock M (2004) Snow accumulation, surface height change, and firn densification at Summit, Greenland: insights from 2 years of in situ observation. J. Geophys. Res., 109, D24113 (doi: 10.1029/2003JD004300)

Ding $M$ and 6 others (2011) Spatial variability of surface mass balance along a traverse route from Zhongshan station to Dome A, Antarctica. J. Glaciol., 57(204), 658-666 (doi: 10.3189/002214311797409820)

Ding $M$ and 11 others (2013) The snowdrift effect on snow deposition: insights from a comparison of a snow pit profile and meteorological observations. Cryosphere Discuss., 7, 14151439 (doi: 10.5194/tcd-7-1415-2013)

Ding $M$ and 7 others (2015) Surface mass balance and its climate significance from the coast to Dome A, East Antarctica. Sci. China Earth Sci., 58(10), 1787-1797 (doi: 10.1007/s11430-015-5083-9)

Domingues CM and 6 others (2008) Improved estimates of upperocean warming and multi-decadal sea-level rise. Nature, 453, 1090-1093 (doi: 10.1038/nature07080)

Drinkwater MR, Floberghagen R, Haagmans R, Muzi D and Popescu A (2003) GOCE: ESA's first Earth Explorer core mission. In Beutler G and others eds. Earth Gravity Field from Space - From Sensors to Earth Science, Space Sciences Series of ISSI, vol. 18. Kluwer Academic Publishers, Dordrecht, Netherlands, 419-432

Drinkwater MR, Francis R, Ratier G and Wingham D (2004) The European Space Agency's Earth Explorer mission CryoSat: measuring variability in the cryosphere. Ann. Glaciol., 39(1), 313-320 (doi: 10.3189/172756404781814663)

Eisen O and 15 others (2008) Ground-based measurements of spatial and temporal variability of snow accumulation in East Antarctica. Rev. Geophys., 46, RG2001 (doi: 10.1029/2006RG000218)

ESRI (Environmental Systems Research Institute) (2014) ArcGIS Desktop: Release 10.2.1. Redlands, CA

Ewert H, Groh A and Dietrich R (2012) Volume and mass changes of the Greenland ice sheet inferred from ICESat and GRACE. J. Geodyn., 59(SI), 111-123 (doi: 10.1016/j.jog.2011.06.003)

Farrell WE (1972) Deformation of the Earth by surface loads. Rev. Geophys. Space Phys., 10, 761-791

Flament N, Gurnis M and Muller R (2013) A review of observations and models of dynamic topography. Lithosphere, 5(2), 189-210

Foley KM, Ferrigno JG, Swithinbank C, Williams RS, Jr and Orndorff AL (2013) Coastal-change and glaciological map of the Amery Ice Shelf Area, Antarctica: 1961-2004. U.S. Geologic Investigations Series Map, U.S. Geological Survey, U. $\mathrm{S}$. Department of the Interior

Fricker HA, Warner RC and Allison I (2000) Mass balance of the Lambert Glacier-Amery Ice Shelf system, East Antarctica: a comparison of computed balance fluxes and measured fluxes. J. Glaciol., 46(155), 561-570 (doi: 10.3189/172756500781832765)

Fricker HA and 5 others (2005) Assessment of ICESat performance at the salar de Uyuni, Bolivia. Geophys. Res. Lett., 32, L21S06 (doi: 10.1029/2005GL023423)

Gunter B and 8 others (2009) A comparison of coincident GRACE and ICESat data over Antarctica. J. Geod., 83(11), 1051-1060 (doi: 10.1007/s00190-009-0323-4)

Haran T, Bohlander J, Scambos T, Painter T and Fahnestock M (2014) MODIS Mosaic of Antarctica 2008-2009 (MOA2009) Image Map (coastline). National Snow and Ice Data Center, Boulder, Colorado

Hoaglin DC, Mosteller F and Tukey W (1983) Understanding Robust and Exploratory Data Analysis. John Wiley \& Sons, Inc., New York, NY

Horwath M and Dietrich R (2009) Signal and error in mass change inferences from GRACE: the case of Antarctica. Geophys. J. Int., 177(3), 849-864 (doi: 10.1111/j.1365-246X.2009.04139.x)

Howat IM, Smith BE, Joughin I and Scambos TA (2008) Rates of southeast Greenland ice volume loss from combined ICESat and ASTER observations. Geophys. Res. Lett., 35, L17505 (doi: 10.1029/2008GL034496)

Ivins ER (2009) Ice sheet stability and sea level. Science, 324(5929), 888-889 (doi: 10.1126/science.1173958)

Ivins ER and James TS (2005) Antarctic glacial isostatic adjustment: a new assessment. Antarct. Sci., 17, 541-553 (doi: 10.1017/ S0954102005002968)

Ivins ER and 5 others (2013) Antarctic contribution to sea-level rise observed by GRACE with improved GIA correction. J. Geophys. Res., 6(118), 3126-3141 (doi: 10.1002/jgrb.50208)

Jekeli C (1981) Alternative methods to smooth the Earth's gravity field. Report 327. Department of Geodetic Science and Surveying, The Ohio State University, Columbus, Oh., USA 
King MA and 5 others (2012) Lower satellite-gravimetry estimates of Antarctic sea-level contribution. Nature, 491(7425), 586-589 (doi: 10.1038/nature11621)

Koenig L, Martin S, Studinger M and Sonntag J (2010) Polar airborne observations fill gap in satellite data. Eos Trans. Am. Geophys. Union, 91(38), 333 (doi: 10.1029/2010EO380002)

Lambeck K (1977) Tidal dissipation in the oceans: astronomical, geophysical and oceanographic consequences. Philos. Trans. R. Soc. Lond. Ser. A, 287(1347), 545-594 (doi: 10.1098/ rsta.1977.0159)

Leick A (2004) GPS Satellite Surveying, 3rd edn. John Wiley \& Sons, Inc., Hoboken, New Jersey, USA, 464 pp

Li J and Zwally HJ (2011) Modeling of firn compaction for estimating ice-sheet mass change from observed ice-sheet elevation change. Ann. Glaciol., 52(59), 1-7 (doi: 10.3189/172756411799096321)

LIMA (Landsat Image Mosaic of Antarctica) (2012) Antarctica Overview Map. http:lima.nasa.gov/pdf/A3_overview.pdf, last accessed on Dec. 10, 2012

Liu J and 6 others (2012) Elevation change of Lambert-Amery system from ICESat/GLAS data. In Paper Presented at the Second Int. Workshop on Earth Observation and Remote Sensing Applications (EORSA), Shanghai, China

Liu XL (2008) Global gravity field recovery from satellite-to-satellite tracking data with the acceleration approach. (PhD thesis, Delft University of Technology, Delft), $226 \mathrm{pp}$

Liu $Y$ and 7 others (2015) Ocean-driven thinning enhances iceberg calving and retreat of Antarctic ice shelves. Proc. Natl. Acad. Sci. USA, 112(11), 3263-3268 (doi: 10.1073/pnas.1415137112)

Luo ZC, Li Q, Zhang K and Wang HH (2012) Trend of mass change in the Antarctic ice sheet recovered from the GRACE temporal gravity field. Sci. China Ser. D, 55(1), 76-82 (doi: 10.1007) s11430-011-4275-1)

Manson R, Coleman R, Morgan P and King M (2000) Ice velocities of the Lambert Glacier from static GPS observations. Earth Planets Space, 52(11), 1031-1036 (doi: 10.1186/BF03352326)

McMillan M and 7 others (2014) Increased ice losses from Antarctica detected by CryoSat-2. Geophys. Res. Lett., 41, 3899-3905 (doi: 10.1002/2014GL060111)

Memin A, Flament T, Rémy F and Llubes M (2014) Snow- and iceheight change in Antarctica from satellite gravimetry and altimetry data. Earth Planet. Sci. Lett., 404, 344-353 (doi: 10.1016/j. epsl.2014.08.008)

Moholdt G, Nuth C, Hagen JO and Kohler J (2010) Recent elevation changes of Svalbard glaciers derived from ICESat laser altimetry. Remote Sens. Environ., 114(11), 2756-2767 (doi: 10.1016/j. rse.2010.06.008)

Moholdt G, Padman L and Fricker HA (2014) Basal mass budget of Ross and Filchner-Ronne ice shelves, Antarctica, derived from Lagrangian analysis of ICESat altimetry. J. Geophys. Res., 119, 2361-2380 (doi: 10.1002/2014JF003171)

Nakada M and 5 others (2000) Late Pleistocene and Holocene melting history of the Antarctic Ice Sheet derived from sea-level variations. Mar. Geol., 167(1-2), 85-113 (doi: 10.1016/S0025 3227(00)00018-9)

NSIDC (2015) Correction to product surface elevations. http://nsidc. $\mathrm{org} /$ data/icesat/correction-to-product-surface-elevations.html, last accessed on 2/24/2015

Paolo FS, Fricker HA and Padman L (2015) Volume loss from Antarctic ice shelves is accelerating. Science, 348(6232), 327331 (doi: 10.1126/science.aaa0940)

Paulson A, Zhong S and Wahr J (2007) Inference of mantle viscosity from GRACE and relative sea level data. Geophys. J. Int., 171(2), 497-508 (doi: 10.1111/j.1365-246X.2007.03556.x)

Reigber C, Lühr H and Schwintzer P (2002a) CHAMP mission status. Adv. Space Res., 30(2), 129-134 (doi: 10.1016/S0273-1177(02) 00276-4)

Reigber C and 9 others (2002b) A high-quality global gravity field model from CHAMP GPS tracking data and accelerometry (EIGEN-1S). Geophys. Res. Lett., 29(14), 37-1-37-4 (doi: 10.1029/2002GL015064)
Rémy F and Parouty S (2009) Antarctic Ice Sheet and radar altimetry: a review. Remote Sens., 1(4), 1212-1239 (doi: 10.3390/ rs1041212)

Ren JW, Allison I, Xiao CD and Qin DH (2002) Mass balance of the Lambert Glacier basin, East Antarctica. Sci. China Ser. D, 45(9), 842-850 (doi: 10.1007/BF02879518)

Rignot E and 6 others (2008) Recent Antarctic ice mass loss from radar interferometry and regional climate modeling. Nat. Geosci., 1, 106-110 (doi: 10.1038/ngeo102)

Rignot E, Velicogna I, van den Broeke MR, Monaghan A and Lenaerts J (2011a) Acceleration of the contribution of the Greenland and Antarctic ice sheets to sea level rise. Geophys. Res. Lett., 38, L05503 (doi: 10.1029/2011GL046583)

Rignot E, Mouginot J and Scheuchl B (2011b) Ice flow of the Antarctic Ice Sheet. Science, 333(6048), 1427-1430 (doi: 10.1126/science.1208336)

Rummel R, Balmino G, Johannessen J, Visser P and Woodworth P (2002) Dedicated gravity field missions - principles and aims. J. Geodyn., 33(1-2), 3-20 (doi: 10.1016/S0264-3707(01)00050-3)

Sabadini R and Vermeersen B (2004) Global dynamics of the Earth: applications of normal mode relaxation theory to solid-earth geophysics. Mod. Approaches Geophys., 20, 329 pp. Springer, Dordrecht, Netherlands

Sasgen I and 6 others (2013) Antarctic ice-mass balance 2002 to 2011: regional re-analysis of GRACE satellite gravimetry measurements with improved estimate of glacial-isostatic adjustment. Cryosphere, 7, 1499-1512 (doi: 10.5194/tc-7-1499-2013)

Schenk T and Csathó B (2012) A new methodology for detecting ice sheet surface elevation changes from laser altimetry data. IEEE Trans. Geosci. Remote Sens., 50(9), 3302-3316

Schutz BE, Zwally HJ, Shuman CA, Hancock D and DiMarzio JP (2005) Overview of the ICESat mission. Geophys. Res. Lett., 32, L21S01 (doi: 10.1029/2005GL024009)

Shepherd A and 46 others (2012) A reconciled estimate of ice-sheet mass balance. Science, 338(6111), 1183-1189 (doi: 10.1126/ science.1228102)

Shuman CA and 6 others (2006) ICESat Antarctic elevation data: preliminary precision and accuracy assessment. Geophys. Res. Lett., 33, L07501 (doi: 10.1029/2005GL025227)

Slobbe DC, Lindenbergh RC and Ditmar P (2008) Estimation of volume change rates of Greenland's ice sheet from ICESat data using overlapping footprints. Remote Sens. Environ., 112(12), 4204-4213 (doi: dx.doi.org/10.1016/j.rse.2008.07.004)

Swenson S and Wahr J (2006) Post-processing removal of correlated errors in GRACE data. Geophys. Res. Lett., 33, L08402 (doi: 10.1029/2005GL025285)

Swenson S, Chambers D and Wahr J (2008) Estimating geocenter variations from a combination of GRACE and ocean model output. J. Geophys. Res., 113, B08410 (doi: 10.1029/2007JB005338)

Takahashi S and Kameda T (2007) Instruments and methods. Snow density for measuring surface mass balance using the stake method. J Glaciol., 53(183), 677-680 (doi: 10.3189/ 002214307784409360)

Tang J, Cheng H and Liu L (2012) Using nonlinear programming to correct leakage and estimate mass change from GRACE observation and its application to Antarctica. J. Geophys. Res., 117, B11410 (doi: 10.1029/2012JB009480)

Tapley BD, Bettadpur S, Watkins M and Reigber C (2004a) The gravity recovery and climate experiment: mission overview and early results, Geophys. Res. Lett., 31, L09607 (doi: 10.1029/ 2004GL019920)

Tapley BD, Bettadpur S, Ries JC, Thompson PF and Watkins MM (2004b) GRACE Measurements of mass variability in the Earth system. Science, 305, 503-505 (doi: 10.1126/science.1099192)

Vaughan DG and 13 others (2013) Observations: Cryosphere. In Stocker and others eds. Climate Change 2013, The Physical Science Basis. Contribution of Working Group I to the Fifth Assessment Report of the Intergovernmental Panel on Climate Change. Cambridge University Press, Cambridge, UK and New York, NY, USA, 317-383 
Velicogna I and Wahr J (2013) Time-variable gravity observations of ice sheet mass balance: precision and limitations of the GRACE satellite data. Geophys. Res. Lett., 40, 3055-3063 (doi: 10.1002/ grl.50527)

Wahr J, Molenaar M and Bryan F (1998) Time variability of the Earth's gravity field: hydrological and oceanic effects and their possible detection using GRACE. J. Geophys. Res., 103(B12), 30205-30229 (doi: 10.1029/98JB02844)

Wahr J, Swenson S, Zlotnicki V and Velicogna I (2004) Time-variable gravity from GRACE: first results. Geophys. Res. Lett., 31, L11501 (doi: 10.1029/2004GL019779)

Wahr J, Swenson S and Velicogna I (2006) Accuracy of GRACE mass estimates. Geophys. Res. Lett., 33(6), L025305 (doi: 10.1029/ 2005GL025305)

Wang H, Wu P and Xu H (2009) A review of research in glacial isostatic adjustment. Progr. Geophys., 24(6), 1958-1967 (doi: 10.3969/j.issn.1004-2903.2009.06.005)

Whitehouse PL, Bentley MJ, Milne GA, King MA and Thomas ID (2012) A new glacial isostatic adjustment model for Antarctica: calibrated and tested using observations of relative sea-level change and present-day uplift rates. Geophys. J. Int., 190, 1464-1482 (doi: 10.1111/j.1365-246X.2012.05557.x)

Wingham DJ and 15 others (2006a) CryoSat: a mission to determine the fluctuations in Earth's land and marine ice fields. Adv. Space Res., 37(4), 841-871 (doi: 10.1016/j.asr.2005.07.027)

Wingham DJ, Shepherd A, Muir A and Marshall GJ (2006b) Mass balance of the Antarctic ice sheet. Phil. Trans. R. Soc. A, 364 (1844), 1627-1635 (doi: 10.1098/rsta.2006.1792)

Yamamoto K, Yoichi F and Koichiro D (2010) Interpretation of GIA and ice-sheet mass trends over Antarctica using GRACE and ICESat data as a constraint to GIA models. Tectonophysics, $\mathbf{5 1 1}$ (3-4), 69-78 (doi: 10.1016/j.tecto.2010.11.010)

Yu J, Liu H, Jezek KC, Warner RC and Wen J (2010) Analysis of velocity field, mass balance, and basal melt of the Lambert
Glacier-Amery Ice Shelf System by incorporating Radarsat SAR interferometry and ICESat laser altimetry measurements. J. Geophys. Res., 115, B11102 (doi: 10.1029/2010JB007456)

Zhang SK, Dongchen E., Wang ZM, Li YS, Jin B and Zhou CX (2008) Ice velocity from static GPS observations along the transect from Zhongshan station to Dome A, East Antarctica. Ann. Glaciol., 48, 113-117 (doi: 10.3189/172756408784700716)

Zhang ZZ, Chao BF, Lu Y and Hsu HT (2009) An effective filtering for GRACE time-variable gravity: fan filter. Geophys. Res. Lett., 36, L17311 (doi: 10.1029/2009GL039459)

Zhao Q and 6 others (2011) GRACE gravity field modeling with an investigation on correlation between nuisance parameters and gravity field coefficients. Adv. Space Res., 47(10), 1833-1850 (doi: 10.1016/j.asr.2010.11.041)

Zwally HJ and Giovinetto MB (2011) Overview and assessment of Antarctic ice-sheet mass balance estimates: 1992-2009. Surv. Geophys., 32, 351-376 (doi: 10.1007/s10712-011-9123-5)

Zwally HJ and Li J (2002) Seasonal and interannual variations of firn densification and ice-sheet surface elevation at Greenland summit. J. Glaciol., 48(161), 199-207 (doi: 10.3189/172756502781831403)

Zwally HJ, Bindschadler RA, Brenner AC, Major JA and Marsh JG (1989) Growth of Greenland ice sheet: measurement. Science, 246(4937), 1587-1589 (doi: 10.1126/science.246.4937.1587)

Zwally HJ and 15 others (2002) ICESat's laser measurements of polar ice, atmosphere, ocean, and land. J. Geodyn., 34(3-4), 405-445 (doi: 10.1016/S0264-3707(02)00042-X)

Zwally $\mathrm{HJ}$ and 7 others (2005) Mass changes of the Greenland and Antarctic ice sheets and shelves and contributions to sea-level rise: 1992-2002. J. Glaciol., 51(175), 509-527 (doi: 10.3189/ 172756505781829007)

Zwally HJ, Giovinetto MB, Beckley MA and Saba JL (2012) Antarctic and Greenland Drainage Systems, GSFC Cryospheric Sciences Laboratory. http://icesat4.gsfc.nasa.gov/cryo_data/ant_grn_drainage_ systems.php. 